NBER WORKING PAPER SERIES

ANNUITY OPTIONS IN PUBLIC PENSION PLANS:
THE CURIOUS CASE OF SOCIAL SECURITY LEVELING

\author{
Robert L. Clark \\ Robert G. Hammond \\ Melinda S. Morrill \\ David Vanderweide \\ Working Paper 23262 \\ http://www.nber.org/papers/w23262
NATIONAL BUREAU OF ECONOMIC RESEARCH
1050 Massachusetts Avenue
Cambridge, MA 02138
March 2017

An earlier version of this paper was prepared for presentation at the 2016 SIEPR Conference on Working Longer. This research is part of an on-going project that is being conducted in partnership with the North Carolina Retirement Systems Division and is being funded by the Sloan Foundation, Grant Number 2013-10-20. The authors gratefully acknowledge the help and support of Janet Cowell, North Carolina State Treasurer, Steven C. Toole, Director of the Retirement Systems Division, Mary Buonfiglio, Deputy Director of Supplemental Retirement Plans, and Sam Watts, Policy Director of the Retirement Systems Division. The authors would like to thank Nino Abashidze, Bryan Allard, Emma Hanson, Christelle Khalaf, and Aditi Pathak for research assistance. The opinions and conclusions expressed herein are solely those of the authors and do not represent the opinions or policy of the North Carolina Retirement System, any other institution with which the authors are affiliated, or the National Bureau of Economic Research.

NBER working papers are circulated for discussion and comment purposes. They have not been peer-reviewed or been subject to the review by the NBER Board of Directors that accompanies official NBER publications.

(C) 2017 by Robert L. Clark, Robert G. Hammond, Melinda S. Morrill, and David Vanderweide. All rights reserved. Short sections of text, not to exceed two paragraphs, may be quoted without explicit permission provided that full credit, including $\odot$ notice, is given to the source. 
Annuity Options in Public Pension Plans:The Curious Case of Social Security Leveling Robert L. Clark, Robert G. Hammond, Melinda S. Morrill, and David Vanderweide NBER Working Paper No. 23262

March 2017

JEL No. H55,J26,J38

\begin{abstract}
Social Security Leveling is an annuity option that allows participants to receive a level income before and after age 62 . The retiree receives a larger pension benefit prior to age 62 , but then the pension benefit is lowered at age 62 when the individual is expected to claim Social Security benefits. This option is not uncommon in public pension plans, yet little is known about how this option is used in practice and its impact on well-being in retirement. Our study uses a combination of administrative records and survey data from recent North Carolina public sector retirees. We find that one-third of all retirees selecting a single life annuity between 2009 and 2014 opted for Social Security Leveling. The evidence suggests that individuals are choosing this option in a way that is consistent with their stated preferences and a consumption smoothing motive. However, we also see higher rates of ex post "regret" in the annuity choice among those choosing the level income option.
\end{abstract}

Robert L. Clark

Poole College of Management

Box 7229

North Carolina State University

Raleigh, NC 27695

and NBER

robert_clark@ncsu.edu

Robert G. Hammond

Department of Economics

North Carolina State University

Raleigh, NC 27695

robert_hammond@ncsu.edu

\author{
Melinda S. Morrill \\ Department of Economics \\ North Carolina State University \\ Box 8110 \\ Raleigh, NC 27695-8110 \\ melinda_morrill@ncsu.edu \\ David Vanderweide \\ Fiscal Analyst \\ Fiscal Research Division \\ North Carolina General Assembly \\ Raleigh, NC 27601 \\ david.vanderweide@ncleg.net
}




\section{ANNUITY OPTIONS IN PUBLIC PENSION PLANS: THE CURIOUS CASE OF SOCIAL SECURITY LEVELING}

\section{Introduction}

One of the most important but understudied choices participants in defined benefit pension plans must make concerns the disposition of funds at retirement. Prior research has explored the tendency of individuals to under-annuitize wealth. ${ }^{1}$ The choice of annuity type in the private sector is heavily influenced by default options as required by the Employee Retirement Income Security Act (ERISA). Public sector plans are not subject to ERISA, and in many states there is no default to a joint and survivor option. Defined benefit plans in the public sector typically allow career retirees to begin full or unreduced benefits at relatively young ages. Individuals retiring in their 50s must determine the best way to receive pension payouts that maximizes well-being over 30 or so years of retirement. These young retirees must also consider the need to finance consumption prior to commencing Social Security benefits as well as in later years of retirement.

This paper explores an annuity option available in some defined benefit plans that allows individuals retiring before Social Security eligibility age to opt to receive a higher initial payment in order to receive a "level" retirement income before and after they start receiving Social Security benefits. In other words, the employer pension benefit received prior to age 62 is equal to the pension plus Social Security benefits after age 62. This annuity option is designed to help retirees smooth consumption, but might have unintended consequences if it encourages

\footnotetext{
${ }^{1}$ For example, see Benatzi, Previtero, and Thaler 2011; Brown et al. 2008; Brown 2001; Chalmers and Reuter 2012; and Butler and Teppa 2007.
} 
overconsumption in the early years of retirement or discourages work after leaving one's career job. It might also encourage earlier than optimal retirement or Social Security claiming. The benefit of this type of borrowing from the pension system, receiving higher benefits prior to age 62 , will be a function of personal preferences over the timing of consumption as well as market interest rates governing the value of spending down wealth to finance consumption.

An option that levels retirement benefits with Social Security benefits is called by various names in defined benefit pension plans including 'Social Security Leveling,' 'Level-up,' 'Level Income,' or 'Accelerated' options. There is limited evidence of some use of this type of annuity option by private plans toward the end of the twentieth century as reported in several articles in the Monthly Labor Review; however, we could find no systematic data indicating the incidence Social Security level income options. ${ }^{2}$ Conversations with senior managers in the Bureau of Labor Statistics and the Office of Policy and Research of the Department of Labor confirm that there were no recent data on private sector defined benefit plans offering Social Security Leveling, and the general assessment was that it is rare to find this type of annuity option in a private plan. In contrast, as shown below, Social Security level income options are rather common in large state-managed public plans.

\footnotetext{
${ }^{2}$ Wiatrowski (1990) reported that data from the 1988 Employee Benefits Survey indicated that one in eight defined benefit plan participants was in a plan that offered a transitional benefit to early retirees; however, these benefits were typically in the form of a "uniform dollar amount for all plan participants regardless of salary or length of service." This type of early retirement incentive is not the same as the annuity option we are examining. Blostin (2003) has a brief statement that indicates that Social Security Leveling was used by some plans but provides no data on how frequent this option is offered and when offered it is selected.
} 
This paper first documents that Social Security level income options are used by about one-third of public defined benefit plans whose participants are also covered by Social Security. We then explore the Social Security Leveling annuity option available to state and local government retirees in North Carolina using both administrative and survey data. We focus on public sector retirees that initiated retirement benefits between 2009 and 2014 and were younger than age 62 at the time of claiming. This analysis indicates that about one-third of those selecting a single life annuity opted for the leveling option, or approximately one quarter of all retirees during this period. In North Carolina, leveling is not an option for retirees who have selected a joint and survivor annuity.

The idea behind offering a level income with Social Security is to allow individuals to borrow against future pension benefits in order to smooth consumption throughout the remaining years of life. However, this option might also appeal to individuals with time-inconsistent preferences or those who see a larger dollar value today without properly considering that claiming will lead to a lower benefit in the future. We provide an example of how personal discount rates will affect the present value of the two benefit options. Similarly, those with shorter life expectancies are likely better off accessing more benefits sooner. We test these predictions using data on recent retirees between 2009 and 2014. We combine administrative records with detailed information from a survey conducted in 2015. These data include subjective life expectancy, household composition, wealth, and self-reported preferences. We observe many of the predicted patterns if individuals selected leveling due to a fully rational consumption-smoothing motive. However, we also find some anomalies that suggest an alternative decision-making rule for some retirees. For example, those individuals who claim the 
level income option report not having enough information when they made retirement-related decisions.

In this study, we focus on individuals who have chosen a single life annuity. ${ }^{3}$ The choice between a single life relative to a joint and survivor annuity is likely to be driven by the value that an individual places on survivor benefits. The importance of survivor benefits is heterogeneous in ways that are complex and would confound the estimation of the choice of interest. By considering only the decision to take the Social Security Leveling option among those who have chosen a single life annuity, we are able to isolate a sample of individuals for whom the importance of a level income before and after age 62 is a predominant motive in their choice of annuity type. ${ }^{4}$

Our analysis illustrates that discount rates used in practice to price the Social Security Leveling option constitutes a relatively expensive way to finance consumption in the period prior to Social Security eligibility. In our setting, the pension system uses a discount rate of 7.25 percent, which is considerably higher than current market interest rates. We find that, if an individual can afford to self-finance consumption in the early years of retirement (i.e., has a personal discount rate below 7.25 percent), the implied cost of borrowing from future benefits yields a lower present discounted value of total pension benefits. This is similar to work by Shoven and Slavov (2014a, 2014b), Goda, et al. (2015), and Bronshtein, et al. (2016), who show

\footnotetext{
${ }^{3}$ Individuals, and their spouses, must make numerous decisions as they near retirement including retirement timing, Social Security claiming, work after retirement, and disposition of wealth from retirement saving plans. Throughout this analysis, we also do not explicitly consider these decisions.

${ }^{4}$ We document that the fraction of benefit claimants choosing a single life annuity is nearly constant over age at claiming, supporting the assertion that individuals first make the choice over single life or joint and survivor annuity and then among the types of annuity in their given choice.
} 
that claiming Social Security early is akin to borrowing from future benefits at a higher than market discount rate.

Our work also contributes to the debate on the welfare implications of the age of Social Security claiming. Shoven and Slavov (2014a, 2014b) argue that, in the current low interest rate environment, it is present-value maximizing for most individuals to delay claiming Social Security, in some cases to delay until age 70. Here "borrowing" from Social Security by claiming benefits at age 62 is costly if one can afford to self-finance consumption until later years and reap the benefit of the delayed retirement credit. Our findings are similar in that it is not beneficial for individuals to borrow from future benefit streams if consumption can be selffinanced at a rate that is favorable compared with the rate of borrowing. The crucial question is how an individual should finance consumption in the early years of retirement and how this impacts future retirement income security. At near-zero real interest rates, liquidating retirement savings (e.g., IRAs) is preferable to early Social Security claiming (Shoven and Slavov, 2014a, 2014b and Goda, et al., 2015). In this study, we illustrate that the key is the relative interest rate of borrowing. For individuals with little to no assets who retire prior to Social Security eligibility might benefit from leveling in order to finance consumption in early retirement years at a rate that is lower than high-interest loans such as credit card debt.

\section{Background on Public Sector Annuity Options}

\section{A. Is Social Security Leveling a Widely Offered Annuity Option?}

Clark and Cowell (2016) reviewed the annuity options of 85 large state-managed public plans which cover teachers, state, and/or local employees and found that 20 of these plans offered a Social Security Leveling annuity option. ${ }^{5}$ Employees and teachers in 17 of the plans

\footnotetext{
${ }^{5}$ These plans are described in bi-annual reports by the Wisconsin Legislative Council (2013).
} 
are not covered by Social Security and so none of these plans offer a leveling option. Thus, about 30 percent of the 68 plans in which participants are included in the Social Security system offer a Social Security Leveling option.

Table 1 lists each public plan with this annuity option along with the type of employees covered by the plan, the number of active workers covered by the plan, and the age at which the pension benefit is reduced if Social Security Leveling is chosen. In total, these plans covered 2.3 million active workers in 2012. Fifteen of the twenty plans specify age 62 as the age at which benefits are reduced while two plans set age 65 , one age 66 , one uses the full retirement age for Social Security benefits, and Virginia allows retirees to select any age between age 62 and the full retirement age for Social Security benefits. ${ }^{6}$ Obviously, only plans in which participants are also covered by Social Security have a level income option. In addition, rules regarding normal and early retirement ages will influence whether the plans will offer a benefit option that links pension benefits to Social Security claiming.

[Table 1]

\section{B. North Carolina Retirement Plans and Annuity Options}

The retirement plan for teachers and state employees and the state-managed pension plan for local employees in North Carolina are typical of state and local pension plans across the country. Teachers and state employees in North Carolina are covered by the Teachers' and State Employees' Retirement System (TSERS), while local government workers participate in the

\footnotetext{
${ }^{6}$ In addition to these 20 plans, Georgia offers its retirees an "Accelerated Benefit" option which if chosen provides a monthly benefit equal to 135 percent of the single life benefit for the first five years of retirement after which time benefits are actuarially reduced.
} 
Local Governmental Employees' Retirement System (LGERS). ${ }^{7}$ Participants in both plans are also generally covered by Social Security. The parameters of the two plans are very similar. ${ }^{8}$ In order to qualify for normal or unreduced benefits, the employee must have satisfied one of three criteria: reached age 65 with 5 years of membership service; reached age 60 with 25 years of service; or have attained 30 years of service at any age. Early retirement with reduced benefits are available to those who have reached age 50 and completed 20 years of creditable service and those who have reached age 60 and completed 5 years of service. Thus, for many public employees in North Carolina, these plans provide a strong economic incentive to retire in their 50 's well before qualifying for Social Security at age 62 .

Upon termination and achieving the age and service requirements, retirees must request from the retirement system that their benefits begin and the annuity option they desire. This is a one-time option and no benefits are paid until the benefit request has been finalized. In other words, there is no default benefit, retirees must submit a request for benefits to be paid, and a choice of payout must be made. Both plans have the same six annuity options which include a single life annuity, a 100\% Joint and Survivors (J\&S), a 50\% J\&S, Social Security Leveling, and

\footnotetext{
${ }^{7}$ The important characteristics of TSERS and LGERS are described in: https://www.nctreasurer.com/ret/Benefits\%20Handbooks/TSERShandbook.pdf and https://www.nctreasurer.com/ret/Benefits\%20Handbooks/LGERShandbook.pdf

${ }^{8}$ Both plans have five-year vesting, the same eligibility and retirement requirements, and are managed by the Department of State Treasurer. There is a slight difference in the generosity of the two plans in that the benefit formula for LGERS is 1.85 percent of final average salary per year of service while the TSERS formula is 1.82 percent of final average salary per year of service. Final average salary is determined by the four highest consecutive years of earnings.
} 
two additional J\&S options with a pop-up provision if the retiree's spouse dies first. Plan actuaries set the terms of all annuity options so that they are present value neutral to the system. ${ }^{9}$

There is also an option to take a lump sum withdrawal. Public sector retirement plans are not subject to ERISA rules regarding the calculation of a lump sum distribution or the requirement that joint and survivor annuities be the default annuity option. Similar to most public defined benefit plans, in TSERS and LGERS lump sum distributions are based solely on employee contributions plus accrued interest. Most benefit claimants with long careers who have attained retirement eligibility find that the present value of the annuity greatly exceeds the lump sum distribution amount (see Clark, Morrill, and Vanderweide, 2014).

The Social Security Leveling option was added to the two North Carolina plans in 1955. In the 1955 leveling option, the benefit assumed Social Security claiming at age 65, which at that time was the earliest age at which one could collect Social Security benefits. In 1959, the target age for leveling was reduced to age 62 for women but age 65 was retained for men. Finally, the terms of the annuity option were amended in 1963 so that both men and women could select Social Security Leveling with the leveling age set at $62 .{ }^{10}$ While we have found no record confirming the reason why the state modified the Social Security Leveling option to target age 62 instead of 65 , one can speculate that the modification was influenced by the change in federal law allowing early claiming at age 62 and the subsequent surge in Social Security claiming age at age 62 .

\footnotetext{
${ }^{9}$ Historically, the General Assembly has awarded cost-of-living adjustments to retirees in both systems that averaged close to the annual increase in CPI; however, in recent years, there have been few increases in benefits.

${ }^{10}$ These changes were driven by changes in federal legislation which first introduced early retirement benefits for women in 1956 and then for men in 1961.
} 


\section{Modeling the Social Security Leveling Benefit}

\section{A. Calculating the Relative Value of the Social Security Leveling Benefit}

The first step in determining the value of the leveling benefit is to calculate the single life annuity benefit, known as the 'maximum benefit,' which is derived directly from the benefit formula specified by the retirement system. The maximum benefit calculation is:

$$
B_{M A X}=\operatorname{Early} * M * Y O S * A F C
$$

We refer to the maximum benefit level as $B_{M A X}$. YOS is the number of years of service at separation, and $A F C$ is the average final compensation calculated using the highest four years of earnings. The pension multiplier, $M$, is 0.0182 for workers in TSERS and 0.0185 for workers in LGERS. Early is an early retirement reduction factor that is imposed for an individual claiming benefits prior to attaining the age and service requirements for unreduced benefits. The reduction factor is a function of claiming age and the number of years the retiree is short of qualifying for unreduced benefits. ${ }^{11}$

Retirees selecting the Social Security Leveling option must submit an estimate of the anticipated Social Security benefit that they will be eligible to receive at age 62 provided by the Social Security Administration based on the assumption that they will not have any further earnings between their retirement and age $62 .{ }^{12}$ The retirement system then calculates an initial

\footnotetext{
${ }^{11}$ For most employees, Early is one minus the lesser of 5 percent per year prior to 30 years of service and 3 percent per year between age 60 and 65 plus 5 percent per year prior to age 60 .

${ }^{12}$ The request for an estimate of the Social Security benefit beginning at age 62 is described in page 35 of https://www.nctreasurer.com/ret/Employers/TSERSEmployerManual.pdf "If, at retirement, the member wants an estimate under Option 4, he or she must furnish the Retirement Systems Division with an estimate, obtained by the member from the Social Security Administration, of the Social Security benefit available to him or her at age 62 . The member should request the age 62 Social Security estimate, in
} 
retirement benefit that can be paid immediately to the retiree and a lower benefit that will be paid after age 62 . The leveling benefits in these two periods are priced relative to the maximum benefit. Before age 62 (period 1), the pension benefit amount is equal to the maximum benefit plus the expected Social Security payment (SS) times a leveling factor, $F$. After age 62 (period 2), the Social Security Leveling pension benefit is equal to the period 1 benefit minus the expected Social Security benefit, thus providing a 'level' income throughout retirement of pension plus Social Security payments.

(1) $B_{L E V}^{1}=B_{M A X}+S S * F$

(2) $B_{L E V}^{2}=B_{L E V}^{1}-S S$

The calculation of the leveling benefit does not depend on whether the individual actually intends to claim Social Security at age 62. The system does not check to see if Social Security benefits are initiated at age 62 or whether the benefit received is equal to the estimated value used for leveling.

The leveling factor is a function of the gender-specific mortality experience of the system, the ratio of male to female retirees, and the interest rate specified by the system. The objective is to determine the period 1 and period 2 benefit amounts so that the present value of the Social Security Leveling option is equal to the present value of the maximum benefit from the perspective of the retirement system. The benefit calculations use gender-specific mortality rates that are then combined using proportions of males and females that reflect the participants in the plan. This process yields a gender-neutral factor.

today's dollars, if he or she stops working at the age he or she will be on his or her effective date of retirement. This estimate should be obtained within 2 years prior to his or her effective date of retirement." 
To calculate the present value of the two benefit streams, the retirement system uses survival probabilities taken from the retirement system's experience study reports and the mortality tables referenced therein. ${ }^{13}$ Both of the North Carolina retirement plans assume that they will earn an annual return on investments of 7.25 percent so that benefit adjustments in the leveling option are made using the expected value of the return that the system could have earned if they had not moved payments forward using the leveling option. ${ }^{14}$ Thus, theoretically the Social Security Leveling option is cost-neutral to the retirement system relative to the Maximum Benefit option, using the assumptions established by the Board of Trustees of the plans.

A simple example illustrates the impact of Social Security Leveling on the amount and time pattern of the pension benefit. Details are provided in Appendix A. We consider a hypothetical retiree claiming benefits at age 57 . We suppose the individual is eligible for a pension of $\$ 2,000$ with the Maximum Benefit option. The retiring worker reports to the retirement system that her expected Social Security benefit at age 62 is $\$ 1,200$. Using this information and the leveling factor, the system would determine that the benefit would be $\$ 2,761$ per month until age 62 and then $\$ 1,561$ per month for the rest of the life of the retiree. Together with a Social Security benefit of $\$ 1,200$, the post-62 total retirement income is 'level' at $\$ 2,761$. Figure 1 illustrates the values of the two options for this hypothetical retiree.

\footnotetext{
${ }^{13}$ Appendix A describes the calculation of the leveling benefit in detail by discussing the development of the leveling factor and how it has changed over time. The system updated its mortality experience in 2012 to reflect improvements in life expectancy, which resulted in higher leveling factors. This change may have made leveling slightly more appealing for post-2012 retirees by a very small amount, but take-up rates for leveling actually dropped slightly.

${ }^{14}$ Most public defined benefit plans assume that they will earn an annual return of between 7.0 and 8.5 percent on their investments. These relatively high assumed returns have been criticized by many economists (Novy-Marx and Rauh, 2011).
} 
[Figure 1]

This calculation does not yield clear guidance on whether the individual is 'better off' receiving a total of $\$ 2,761$ per month beginning when the pension benefit is first claimed for the remainder of her life or receiving $\$ 2,000$ per month in pension benefits prior to age 62 and then a total of $\$ 3,200$ per month after age 62 (i.e., $\$ 1,200$ per month from Social Security and $\$ 2,000$ per month from the pension). Answering this welfare question is complicated by a number of factors. If an individual plans to continue paid employment after claiming a pension benefit, then she may not need to access pension benefits early to smooth consumption. If an individual has a shorter than average life expectancy due to poor health, she may benefit from receiving the higher benefit earlier. And, of course, a high personal discount rate will lead one to more highly value the near term larger income stream.

By design, Social Security Leveling and Maximum Benefit options are supposed to be cost neutral to the system. Thus, if an individual has a personal discount rate of 7.25 percent, the present value of leveling would be the same as that for the Maximum Benefit option.

Economists have argued that a lower personal discount rate such as 2.9 percent would be a more reasonable representation of the rate used by the average retiree. ${ }^{15}$ This rate is also more closely aligned with potential market yields to an individual investor. The assumed lower discount rate used by the retiree results in a higher present value of both benefit options. However, under lower personal discount rates the present value of the Maximum Benefit would be higher than that of the Social Security Leveling option. Clearly the relative "value" to the retiree of the two options hinges on an individual's personal discount rate and need to smooth consumption.

\footnotetext{
${ }^{15}$ See Shoven and Slavov (2014a, 2014b) for a discussion of appropriate discount rates for recent retirees.
} 
Table 2 illustrates the relative value of Social Security Leveling and the Maximum Benefit Option for the hypothetical retiree described above. We calculate the present value of each annuity stream using a series of personal discount rates ranging from zero to 14.5 percent. These discount rates can be thought of as reflecting preferences and/or market conditions for borrowing. Given that the formula used to determine the relative value assumes a 7.25 percent discount rate, it should not be surprising that at a personal discount rate of 7.25 percent the Leveling and Maximum Benefit options are basically equivalent. Individuals with lower discount rates should prefer the benefit option that yields a higher value in the later years of retirement. For example, if this individual had a 2.9 percent discount rate, she would have a 7.0 percent higher lifetime present value if she selected the Maximum Benefit instead of Social Security Leveling option. This difference is even larger with no discounting where Maximum Benefit is 11 percent higher. On the other hand, for very high personal discount rates, the present value of the lifetime benefit will be higher for Social Security Leveling. High personal discount rates could be due to time preferences or due to lack of liquidity in the pre-age 62 years.

[Table 2]

If an individual believes she has a higher life expectancy than the retirement system's assumptions, she will clearly receive a higher lifetime benefit from choosing the Maximum Benefit option. However, the prediction for age at claiming is less clear. As shown in Appendix A, if an individual has a discount rate below 7.25 percent, then the "penalty" associated with leveling is more pronounced for those that claim benefits at younger ages. However, claiming benefits at younger ages is associated with individual characteristics that might otherwise affect the relative weighting of the two plans including subjective life expectancy and personal 
discount rates. Thus, the simulation exercise does not yield a clear prediction on how the choice of leveling is related to age at claiming.

\section{B. Theoretical Predictions Regarding Saving and Borrowing in Retirement}

The calculations described above support the prediction that individuals with higher personal discount rates and lower life expectancies will be more likely to choose leveling. To test this empirically, we now describe how these and some related theoretical predictions translate into testable hypotheses in our data. Table 3 summarizes the predictions under a consumption smoothing motive for choosing the Social Security Leveling option.

[Table 3]

First, there are several factors that contribute to how individuals weigh present versus future income and consumption. Time preferences matter explicitly such that an individual who discounts the future more highly is more likely to choose leveling. Similarly, those who are time impatient are less likely to invest in human capital, thus we predict that those with lower education and poorer health are more likely to choose leveling due to underlying time preferences. One related factor that contributes to time impatience is the lack of liquidity or access to borrowing. If an individual has ample retirement savings, she may access these funds at little or no cost. Thus, we predict that individuals who have accumulated retirement wealth are less likely to choose leveling. These factors are summarized in the first row of Table 3 .

Liquidity itself will be related to the choice of the leveling option. An individual that has other sources to borrow from will be less likely to elect for the leveling option if the implied discount rate is lower than 7.25 percent. To the extent that pension size and final average salary are correlated with having accumulated significant supplemental retirement wealth, we predict that those with larger pension benefits are less likely to choose leveling due to the outside 
options for borrowing. Holding constant wealth, the absolute size of the pension should only be related to the choice of leveling if an individual is liquidity constrained and finds the pension benefit insufficient to finance current consumption.

An individual who is married to someone who is currently employed or who has previously been employed is likely to have other options for smoothing consumption. However, an individual who is the primary earner in the household might have a stronger incentive to borrow, particularly if his/her spouse is in poor health or has immediate consumption needs. Thus, we expect single individuals and primary earners to be more likely to elect for leveling relative to married individuals who are not the primary or sole earner. Finally, the prediction for years of service is ambiguous in this context. On the one hand, longer tenures are associated with higher pension benefits and more human capital. However, a shorter tenure might be due to prior work experience or could reflect an endogenous choice to retire early and pursue a second career. These factors are summarized in the second row of Table 3.

Next, all else equal, those with lower life expectancies should prefer Social Security Leveling. Given that the retirement system prices the plans based on a blended life expectancy between men and women, the leveling option is relatively more favorably priced for men with average life expectancy than for women with average life expectancy. Gender may also proxy for other characteristics, however, so must be interpreted with caution. Similarly, those without a college degree have lower life expectancies, so lower educated may be more likely to choose leveling due to shorter life expectancy. And, to the extent that race/ethnicity correlates with life expectancy, we expect that non-Hispanic blacks are more likely to choose leveling than nonHispanic whites. These factors are summarized in the third row of Table 3. 
The prediction for the relationship between age at retirement and the choice of leveling is more complicated, as discussed in Section III.A. Empirically, we fix the age at claiming benefits and so are comparing only individuals at the time when they are making the claiming choice. Individuals that work during retirement or have access to other sources of income are more likely to prefer the Maximum Benefit. And, individuals that retire at younger ages could plan to work in retirement. However, a longer time until retirement might mean more of a need to smooth consumption. Holding constant subjective mortality expectations, personal discount rate, and the absolute level of benefits, we find no clear prediction on the relationship between age at claiming and annuity option choice.

Next, while individuals in poor health may have lower life expectancies, even controlling for years spent in retirement (i.e., age at claiming and subjective mortality), the prediction for the relationship between poor health and annuity choice is ambiguous. Individuals may require additional funds for medical expenditures if they are in poor health. Similarly, individuals in good health may wish to "save" more by not choosing leveling guaranteeing a higher income in later years when health may be worse. Or, individuals may want to consume more during a period of good health.

Some more ambiguous predictions arise from considering additional individual characteristics. Risk aversion could manifest itself in a preference for leveling if near-term consumption shocks are predominant in one's decision process. However, if mortality risk (i.e., dying young) is predominant, then one is likely to prefer immediate consumption and therefore choose leveling. If instead an individual is worried about longevity risk (i.e., outliving one's savings), the individual is less likely to prefer leveling so that the benefit in later years is higher. Thus, the prediction on risk preferences is ambiguous. Finally, we note here that financial 
knowledge yields no prediction under consumption smoothing. The consumption smoothing framework assumes perfect information and rational decision-making. Thus, if financial knowledge were related to the choice of leveling, we would interpret that as evidence of an alternative decision-making rule.

\section{Social Security Leveling Option Choice Among Recent Retirees}

\section{A. North Carolina Retirement Systems Data}

To shed some light on the relative importance of the hypotheses described in Section III, we analyze data on older public sector workers in the North Carolina Teachers' and State Employees' Retirement System (TSERS) and Local Governmental Employees' Retirement System (LGERS). We perform our analysis using a matched dataset of administrative records and survey data. We obtained administrative data files for all participants in TSERS and LGERS who initiated pension benefits between 2009 and 2014. The administrative records contain detailed information about each retiree including earnings, job information, years of service, creditable service, year of retirement, annuity option chosen, and benefit amount. From the universe of recent retirees, we sent a survey to a random sample in Spring 2015. The survey obtained additional personal information not contained in the administrative questions about race/ethnicity, education level, household income and wealth, work status after claiming retirement benefits and marital status, along with questions about their spouses' characteristics (if applicable) and time spent caregiving. In addition, the survey included questions on retiree well-being and satisfaction with retirement-related decisions. ${ }^{16}$

It is important to note that the survey responses were received in 2015 one to five years after the retiree had made their choice of the pension annuity. Thus, some answers (such as

\footnotetext{
${ }^{16}$ Appendices $\mathrm{B}$ and $\mathrm{C}$ provide detail on the data and survey instrument.
} 
wealth and health) may differ from those the individual might have given at the time of the retirement decision.

Table 4 presents the means of the full administrative dataset along with the subset of individuals that were sent and then responded to the survey. The total number of recent benefit claimants is 72,350, shown in Table 4, Column (1). Of these, 36,883 retired prior to age 62 and were thus eligible for the leveling option (see Column (2)). Column (3) reports means when the sample is further limited to only individuals who selected a benefit based on a single life annuity (in other words, the Maximum Benefit or Social Security Leveling options). We then merge this set of records with the survey data. The survey was sent to 9,650 individuals from the population in Column (3). Our estimation sample includes 2,256 useable responses, which represents a survey response rate of roughly $23 \% .{ }^{17}$ Column (4) provides sample means for our survey respondent. Comparing Columns (3) and (4), we see that our survey sample is reasonably representative of the population of interest. Some notable differences are that the survey respondents tended to have higher final average salary and maximum initial benefit amounts and were more likely to have more than 30 years of service at retirement.

[Table 4]

Considering the means reported in Table 4, Column (2), we see that almost two-thirds of individuals retiring before age 62 had sufficient years of service to be eligible for an unreduced retirement benefit. About 80 percent of all retirees were state employees and teachers with the remainder being city and county employees throughout the state. The average age of starting

\footnotetext{
${ }^{17}$ The survey is part of a larger project and covers all benefit claimants from 2009 to 2014 . Our overall response rate on the survey was $22 \%$. For more detail on the larger project, please see our website: https://sites.google.com/site/publicsectorretirement/. Note that Column 4 excludes two survey respondents who met all other criteria but who have both a TSERS and LGERS account.
} 
retirement benefits for all retirees is 60.7 and for those that retired prior to age 62 , the mean age is 56.9. In general, the public sector tends to be majority female as the modal occupation is teacher. The North Carolina data are consistent with this observation as about two-thirds of the retirees during the sample period were women. Interestingly, when comparing Columns (2) and (3), we note that a higher percentage of women compared to men select a single life annuity.

The initial question for this research is whether Social Security Leveling is an important annuity option for retirees. In other words, is Social Security Leveling simply a curious anomaly made available to public employees or an important annuity choice that demands attention and therefore should be a topic for policy review? We do find evidence that North Carolina public sector retirees utilized this annuity option. At the bottom of Table 4, we see that 23.4 percent of retirees younger than age 62 chose the leveling option. If the sample is restricted to individuals who chose a single life annuity, in Table 4, Column (3), we see 33.4 percent of these retirees opted for Social Security leveling.

To illustrate the pattern of annuity choice by age, Figure 2 plots the annuity type chosen by age at benefit claiming. Here the annuity types are grouped in three categories: (1) Social Security Leveling, (2) Maximum Benefit, or (3) a Joint and Survivor Option. We can see that the ratio of single life to joint and survivor annuity options is relatively constant. Above, we describe how our prediction for the relationship between age at claiming and selection of leveling was ambiguous, holding all else equal. We see in Figure 2 that about half of all individuals claiming a single life annuity prior to age 55 chose Social Security Leveling. This rate declines by age at claiming, with very few selecting leveling at age 61 . This relatively high rate of selecting Social Security Leveling among younger retirees highlights the importance of an analysis of why retirees find this to be their preferred form of income in retirement. 
[Figure 2]

An individual makes many decisions leading up to the point of choosing Social Security Leveling. Near the end of her career, she chooses the timing of separation and retirement benefit claiming. At that point, she chooses whether to withdraw funds as a lump sum, take a joint and survivor annuity, or take a single life annuity. We assume that once a retiree has decided on a single life annuity, she then decides between the Maximum Benefit option, which provides a constant monthly benefit for life, or the Social Security Leveling option, which offers a higher benefit before age 62 followed by a lower benefit after age 62 . Although we model only the decision made between the Maximum Benefit and the Social Security Leveling options once all other decisions have been made, we note that any parameters that impact prior choices will in turn affect the sample composition of who might be facing the Social Security Leveling option choice. We make this restriction because for this sample the importance of a level income before and after age 62 is a predominant motive in their choice of annuity type. In contrast, we anticipate heterogeneity in the importance of survivor benefits offered in the joint and survivor annuity options in ways that would confound the estimation of the choice of interest. Thus, we estimate the how individual characteristics predict the choice of taking the leveling option among only those that have elected for a single life annuity.

\section{B. Social Security Leveling Uptake Among Retiring Workers in North Carolina}

In Section III and Table 3, we outlined several characteristics that we predict would lead individuals to select the Social Security Leveling option over the Maximum Benefit option. We predict that individuals with higher personal discount rates and lower life expectancies will be relatively more likely to choose the leveling option. We anticipate that unobserved personal discount rates and predicted life expectancy are correlated with observable demographic and 
socioeconomic characteristics. We thus predict higher take-up of leveling among men, nonHispanic black individuals, those with lower education levels, and those with less wealth accumulated. We find support for all of these hypotheses in our regression analysis described below.

Our main regression analysis is estimated using data that consists of survey responses merged with administrative data, as shown in Table 4, Column (4). Our main sample is individuals who claimed benefits at an age younger than 62 and selected a single life annuity (i.e., either the Maximum Benefit or Social Security Leveling options). The survey of retirees provides us with the opportunity to examine annuity choice process utilizing personal information that is not available in the administrative records. As noted above, individuals were surveyed in 2015, so the responses are between one to five years after initiating retirement benefits. Tables 5-7 present regression estimates from a linear probability model of selecting the leveling option among those who selected a single life annuity at retirement. ${ }^{18}$ Table 5, Column (1) presents results from the baseline specification. This specification is repeated in Tables 6 and 7 for reference. Tables 5 and 6 allow us to assess consumption smoothing as a motivation for choosing Social Security Leveling.

[Table 5]

\footnotetext{
${ }^{18}$ In addition to the covariates presented in the table, the regression model also includes indicators for having multiple benefit accounts. As described in more detail in the appendix, individuals have the option to combine accounts or to claim accounts separately. If an account has been combined, we only observe the merged account in the data. Thus, opting to keep the accounts separate indicates something about an individual's preferences regarding pension payouts. The baseline specification also includes controls for five agency categories and for the year of benefit claiming.
} 
First in Column (1) of Table 5, as predicted, men are 4.7 percentage points more likely to choose leveling. This is consistent with the fact that men have shorter life expectancies, on average, so that the ratio of the present value of leveling relative to maximum benefit is higher for men than women. ${ }^{19}$ We see no differences by marital status. ${ }^{20}$ Non-Hispanic black retirees are significantly more likely to choose leveling, perhaps again due to shorter anticipated life expectancies. Individuals with at least a Bachelor's degree are 6.6 percentage points less likely choose leveling, which is consistent with lower life expectancy and a higher personal discount rate.

There is a clear age pattern as each year of age at the time of claiming results in a lower probability of choosing leveling of 3.6 percentage points. While this is consistent with individuals further from Social Security eligibility age having a stronger need to smooth consumption, it is not consistent with younger individuals having a higher potential to engage in post-retirement work. Note that the estimated coefficient on age at claiming is holding constant years of service and benefit amount. For years of service, the omitted category is having at least 30 years of service. We see no statistically significant differences by years of service when controlling for age and benefit amount. We observe that a higher maximum initial benefit amount is associated with a lower take-up of leveling. As discussed in Section III, liquidity constraints would suggest that those with a lower pension benefit, all else equal, would be more likely to choose leveling.

\footnotetext{
${ }^{19}$ To measure the magnitude of this gender difference, we compare the present value difference between the maximum benefit and the leveling annuity for a man and woman both of whom have a personal discount rate of 2.9 percent. Using the same characteristics as described above, the present value of gain of the maximum benefit compare to the leveling option is $\$ 30,000$ for women and $\$ 24,000$ for men.

${ }^{20}$ Recall that the estimation sample excludes individuals choosing a Joint \& Survivor annuity option.
} 
The baseline results presented in Column (1) of Table 5 suggest those with statistically lower life expectancies (men, lower educated, non-Hispanic black) are all more likely to choose the leveling option. While we do have survey responses on health status and subjective survival expectations, these are measured in our survey some time after the annuity decision was made. It may be that causality flows from having chosen leveling to health. For example, the higher short-run benefit received under leveling could lead to a more muted health decline in retirement. Prior literature has found that health declines around the time of retirement and that this is probably both a cause of retirement and an effect of retirement (see, e.g., McGarry 2014). Our theoretical prediction is that those in poorer health will be more likely to choose leveling because they have a shorter life expectancy. The estimated coefficients on demographic characteristics presented above are consistent with this prediction. But, if having a higher benefit in retirement allows levelers to insulate themselves better from post-retirement health shocks, then the estimated coefficient on health status measured ex post will confound both underlying health prior to retirement and post retirement health status. Thus, we cannot directly interpret the coefficients on health or subjective mortality expectations when measured ex post.

However, we can consider whether the estimated coefficients on demographic characteristics are altered when including ex post health and mortality measures. In Column (2) of Table 5, we include self-reported health status and perceived life expectancy. We include a dummy variable for reporting being in "fair" or "poor" health (relative to reporting "good," "very good," or "excellent" health). We also report the estimated coefficient on a dummy variable for having skipped the health status question. We observe that those in poor health in retirement are less likely to have chosen the leveling option, consistent with the prediction that ex post health is improved for levelers. High life expectancy is defined as predicting one's 
mortality as greater than 80 years. We do not observe a statistically significant relationship with self-reported (ex post) subjective mortality and choosing the leveling option. The estimated coefficients on the demographic characteristics are basically unchanged when adding the health and mortality covariates to the model. To the extent that our health and mortality measures are correlated with pre-retirement health status, they cannot explain the associations observed between choosing leveling and being male, lower educated, and not white.

Next, we explore the role of time and risk preferences in Column (3) of Table 5. Once again, we are using ex post measures of risk and time preference. We are assuming that over the interval between retirement and the survey, these preferences would have remained relatively stable. We have two measures of time preferences drawn from Health and Retirement Studystyle hypothetical choice survey questions. We include three dummy variables to capture individuals who are classified as impatient on only one frame or both, relative to the omitted group of patient on both. Risk preferences are proxied using similar questions; these were also designed to match questions in the Health and Retirement Study and are used to construct binary measures similar to what we use for time preferences. Appendix $\mathrm{C}$ provides more information on our time and risk questions. In Section III and in Table 3, we discuss how the predictions for time impatience are clear: those who prefer immediate consumption to delayed consumption should prefer Social Security Leveling. However, the prediction for risk preferences is ambiguous.

As predicted by consumption smoothing, impatient individuals are more likely to choose leveling because it is associated with higher monthly benefits in the near term. Those who were found to be impatient on both frames are the most likely to choose leveling but the differences across frames are not large. In contrast, there is less of a clear pattern in the choice of leveling 
for more or less risk averse individuals across our two risk frames. All point estimates are consistent with more risk averse individuals choosing leveling more often but the standard errors are large. Further, the differences in coefficients for each risk dummy are not statistically significant. In total, we find strong support for a preference for leveling among the impatient and directional support for a preference for leveling among the risk averse. While the estimated coefficients on education and race do drop slightly, suggesting preferences play some role in explaining the differences across these groups, the coefficient on male actually increases slightly.

Next, in Table 6, we explore whether accumulated wealth is associated with the decision to take the Social Security Leveling annuity option. Again, these measures are gathered in retirement and must be interpreted with some caution. However, if individuals who chose the Maximum Benefit option have already spent down wealth, then the association between low levels of wealth and leveling choice will be diminished. In Table 6, Column (1), we repeat the baseline specification for reference. In Column (2), we add measures of self-reported retirement saving plan balances and summary wealth variables. We see that those reporting smaller account balances and lower wealth levels are significantly more likely to have chosen the Social Security Leveling option at retirement. Note that, to the extent that wealth will decline more for those not choosing leveling, the wealth results are potentially biased towards, not away, from zero. Again, we see that wealth explains little of the demographic group differences.

[Table 6]

The results discussed thus far provide some evidence of consumption smoothing as a key factor in explaining the choice of a leveling annuity option. However, while several groups with lower life expectancy are more likely to choose leveling (men, non-Hispanic blacks, and individuals without a college degree), we find no association between (ex post) self-reported life 
expectancy and choosing leveling. Individuals who appear more impatient are also more likely to choose leveling, which is again consistent with a consumption smoothing motive. Next, we ask whether a behavioral decision rule also plays a role.

\section{Myopic Benefit Maximization}

Individuals motivated by consumption smoothing are conforming to well-known decision rules advocated by economists. However, questions remain about the empirical validity of consumption smoothing as a predominant factor in explaining intertemporal consumption and savings behavior (e.g., Angeletos, et al., 2001, and Camerer, Loewenstein, and Prelec, 2005). Alternatively, myopic benefit maximization as a motivation for choosing Social Security Leveling could be used to describe the behavior of some retirees. Under myopic benefit maximization, individuals who are attracted to a higher immediate benefit (perhaps because they place a high weight on immediate consumption needs) perceive their retirement and other asset holdings at separation as insufficient. In short, some individuals may choose Social Security Leveling because they feel that they need the larger benefit now without internalizing the fact that the benefit will be lowered in the future. Here, we assess whether there is evidence that is consistent with myopic benefit maximization, controlling for the factors predicted by consumption smoothing.

Myopic benefit maximization would predict that those with lower education and less financial sophistication would be more attracted to the leveling option. The previous section has noted that individuals with a college degree are meaningfully less likely to choose leveling. We cannot test between a fully rational consumption smoothing rule and a myopic rule as explaining why less educated individuals prefer leveling. Low educational attainment is consistent with myopic decision making in other contexts (e.g., Boissiere, Knight, and Sabot 1985 and 
Benjamin, Brown, and Shapiro 2013). In contrast, the smoothing explanation posits that less educated individuals recognize their shorter life expectancy and optimally choose leveling in response. $^{21}$

For a further look at myopic benefit maximization as explaining the choice of leveling, we explore the role of financial literacy. Our approach builds on the growing literature on financial literacy and retirement decision making. The myopic decision rule predicts that leveling is more likely to be chosen by less financially literate individuals. To test this, we introduce two measures of financial literacy drawn from the survey: objective financial literacy and subjective financial knowledge. The objective measure includes three dummy variables for whether the individual correctly answered questions drawn from the Health and Retirement Study. The subjective measure is a self-reported financial literacy score on a scale from 1 to 7 , with blank responses coded as zero and a dummy variable for blank response included.

Table 7 presents results from regressions including these variables. First, Column (1) repeats the baseline specification for reference. Then, Column (2) includes the "objective" financial literacy measures. The specification also includes indicators for skipping the "objective financial knowledge" questions. The coefficients are not statistically significant and are not presented for brevity. Individuals answering one or both of the financial knowledge questions correctly are no more or less likely to have chosen the leveling option. Again, these responses are measured between one and five year after the claiming decision was made and might confound any learning that occurred in the interim.

\section{[Table 7]}

\footnotetext{
${ }^{21}$ The smoothing calculus for why men choose leveling more often than women is arguably more plausible, given the gender difference in life expectancy is well known among the general public.
} 
Table 7, Column (3) includes subjective financial knowledge. We include a linear term for self-reported financial knowledge on a scale of 1-7, with a missing value treated as zero. We also include an indicator for skipping the self-reported financial knowledge question (which was the last question on the survey). Individuals with high subjective financial knowledge are no more or less likely to choose leveling. Furthermore, including both objective and subjective financial literacy does not meaningfully alter the estimated coefficients on the other included demographic characteristics. These results suggest that residual variation in financial literacy is uncorrelated with the choice of leveling.

Finally, we explore a mismatch between objective and subjective knowledge by including a variable of "overconfidence" that is defined as not answering both financial literacy questions correctly but reporting at least a 5 out of 7 on self-reported financial knowledge. We again see no statistically significant relationship here. These results do not support the myopic rule as an important factor and suggest that there is no statistically significant difference in the choice of leveling for those with lower knowledge or financial sophistication.

While we find no systematic evidence that those with poor financial literacy are more attracted to the Social Security Leveling option, that does not imply that financial literacy is unimportant in retirement-related decision making. For example, individuals with poor understanding of pension plan incentives might be attracted to the term "Maximum Benefit" option and take that as an implicit default. Chan and Stevens (2008) find evidence that individuals respond to perceived pension incentives, even when ill-informed. In total, we find limited support for an alternative, behavioral decision rule, myopic benefit maximization. 


\section{Ex-Post Regret in Retirement}

In the survey data, we observe several measures of retirees' satisfaction with their retirement choices and the information available upon annuity choice. If individuals are choosing leveling simply to receive a larger payment initially, we would observe that the ex-post regret measures will differ for individuals who are responding to the survey before and after age 62. In contrast, if consumption smoothing explains the choice of leveling, we should observe no large differences in post-retirement regret across annuity type and no large changes at age 62.

Table 8 presents these results. In each column, the dependent variable is whether the individual "strongly agrees" with statements about retirement income security and information. ${ }^{22}$ Each column presents the results from an LPM model, where the ex-post regret measures are as follows: whether the individual reported having saved enough for retirement, reported having been able to maintain a satisfactory standard of living, and reported that they had enough information when making their annuity choice.

\section{[Table 8]}

The results in Table 8 show differences in the ex-post regret measures from individuals who chose leveling, relative to the Maximum Benefit option, separately for individuals who are responding to the survey prior to age 62 and post 62 . The pre- 62 respondents that chose leveling are currently receiving the higher benefit from the pension system, while the post-62 respondents are currently receiving the reduced benefit. However, for levelers, their pension plus Social Security income is equivalent before and after age 62. On the other hand, those choosing the Maximum Benefit option will be receiving a higher level of income from pension plus Social Security after age 62 .

\footnotetext{
${ }^{22}$ The wording of these questions is included in Appendix C.
} 
In Table 8, Column (1), we observe that a higher proportion of those that selected Social Security Leveling felt that they had not saved enough for retirement. For retirees who responded after age 62 , levelers are around nine percentage points less likely than those choosing the Maximum Benefit option to say they saved enough for retirement. This is a large difference and is consistent with myopic behavior playing a role in the choice of leveling.

In Table 8, Column (2), for pre-62 respondents, levelers are around eight percentage points more likely to report being able to maintain their standard of living in retirement. However, for post-62 respondents, levelers and non-levelers report being able to maintain their standard of living at similar rates. Thus, for those individuals whose pension benefit has been reduced at age 62, the perceived benefit to standard of living afforded by Social Security Leveling has gone away. When considering the role of information in Column (3), we see that those retirees that have passed the age 62 threshold are 6 percentage points less likely to report having had enough information about their annuity options at retirement if they leveled. A significant group of levelers who are now in the lower-benefit period (i.e., post-62) no longer believe they had enough information when they chose their benefit, which is consistent with regret. Note that the mean of the dependent variable is 0.841 indicating that the majority of respondents did feel that they had sufficient information at the time of decision-making.

We interpret the results in Table 8 as suggestive evidence of ex-post regret associated with the choice of Social Security Leveling. There are meaningful differences at age 62 in respondents' perceived satisfaction with their standard of living and the information available at the time of annuity choice. These facts undermine a fully rational model of the choice of leveling based on consumption smoothing. 
In total, the results in Table 7 provided only limited support for an alternative, behavioral model of the choice of leveling. While less educated individuals are significantly more likely to choose leveling, there is no evidence that low levels of financial literacy are the cause. But, from Table 8, individuals who chose leveling report that they had not saved enough and, once the benefit drops at age 62 , do not feel they had enough information when they chose leveling. The richness of our data allow us to combine the evidence from these two approaches to assess the residual explanatory power of an alternative, behavior decision rule. We conclude that myopic benefit maximization does play a role in understanding which individuals select the Social Security Leveling annuity option.

\section{Discussion and Future Work}

Social Security Leveling is an annuity option offered by 20 large public defined benefit plans. The experience of recent retirees in North Carolina shows that a substantial proportion of younger retirees are selecting this option, which changes the lifetime pattern of their retirement income. Clearly, Social Security Leveling is not merely just a curious oddity but instead is a significant policy issue that merits consideration and review.

We have documented that the retirement system offers leveling in a manner that is cost neutral to the system. The pricing is based on an interest or discount rate of 7.25 percent. This is the same rate that the system assumes that it will make on its investments. It seems unlikely that individuals in today's economic climate would use such a high discount rate for future income when market interest rates hover near zero. Our calculations show that when individuals use a lower discount rate, the present value of the Social Security Leveling annuity is less than the present value of the Maximum Benefit annuity. Thus, for a typical retiree, Social Security Leveling would seem to be a suboptimal choice from a present-value perspective. 
Despite this finding, it is easy to see why some retirees will select the leveling option. Individuals that are liquidity constrained or do not have access to low interest debt may find that leveling is a better option than other sources of credit. Individuals with shorter than average expected lifetimes will have a higher present value of benefits paid under leveling compared to the maximum benefit. Retirees with immediate income needs may also find leveling a superior choice. Thus, individual and household differences can explain some of the sorting of retirees into those selecting leveling as their best option. We report evidence that suggests those with lower levels of wealth and groups with lower life expectancies are more likely to choose the leveling option. We also observe that individuals exhibiting time impatience are more likely to choose leveling. We do not find strong evidence that leveling is more popular among those with lower levels of financial literacy. However, we do find evidence of ex post "regret" in retirement among levelers.

Is Social Security Leveling at age 62 a wise public policy? The answer to this question depends on how having the option to level income affects other choices by retirees. Using our combined administrative records and survey data, we provide a detailed analysis of annuity choice in a setting where there is no default annuity option. We find evidence that is consistent with the choice of Social Security Leveling as part of a fully rational consumption-smoothing plan. However, we also find some evidence that myopic benefit maximization is a component of the choice of the leveling option for at least some retirees. In total, our interpretation is that the evidence is mixed in terms of how well Social Security Leveling works for retirees in this setting. One message of these results is for an emphasis (or further emphasis) on the potential advantages and disadvantages of particular annuity options in the information provided to retirees by the retirement system. 


\section{REFERENCES}

Angeletos, G.M., Laibson, D., Repetto, A., Tobacman, J. and Weinberg, S., 2001. "The hyperbolic consumption model: Calibration, simulation, and empirical evaluation," Journal of Economic Perspectives, 15(3), pp.47-68.

Benartzi, Shlomo, Alessandro Previtero, and Richard Thaler. 2011. "Annuitization puzzles," Journal of Economic Perspectives, 25(4): 143-164.

Benjamin, D.J., Brown, S.A. and Shapiro, J.M., 2013. "Who is 'behavioral'? Cognitive ability and anomalous preferences," Journal of the European Economic Association, 11(6), pp.1231-1255.

Blostin, Allan. 2003. "Distribution of retirement income benefits," Monthly Labor Review, April, pp. 3-9.

Boissiere, M., Knight, J.B. and Sabot, R.H., 1985. "Earnings, schooling, ability, and cognitive skills." American Economic Review, 75(5), pp.1016-1030.

Bronshtein, Gila, Jason Scott, John Shoven, and Sita Slavov. 2016. "Leaving big money on the table: Arbitrage opportunities in delaying Social Security” NBER Working Paper \#22853, November 2016.

Brown, Jeffrey. 2001. "Private pensions, mortality risk, and the decision to annuitize," Journal of Public Economics, 82(1): 29 - 62.

Brown, Jeffrey R., Jeffrey R. Kling, Sendhil Mullainathan, and Marian V. Wrobel. 2008. "Why Don’t People Insure Late-Life Consumption? A Framing Explanation of the UnderAnnuitization Puzzle," American Economic Review: Papers \& Proceedings, 98:2, 304309.

Bütler, M., and Teppa, F. 2007. "The choice between an annuity and a lump sum: Results from Swiss pension funds.” Journal of Public Economics, 91(10), 1944-1966.

Camerer, C., Loewenstein, G. and Prelec, D., 2005. "Neuroeconomics: How neuroscience can inform economics." Journal of Economic Literature, 43(1), pp.9-64.

Chalmers, J., and Reuter, J. 2012. "How do retirees value life annuities? Evidence from public employees," The Review of Financial Studies, 25(8): 2601-2634. 
Chan, Sewin and Ann Huff Stevens. 2008. "What you don't know can't help you: Pension knowledge and retirement decision-making," The Review of Economics and Statistics, 90(2): 253-266.

Clark, Robert and Janet Raye Cowell. 2016. "Annuity Options in Public Pension Plans,” Pension Research Council Annual Conference, May.

Clark, Robert, Melinda Morrill, and David Vanderweide. 2014. "Defined Benefit Pension Plan Distribution Decisions by Public Sector Employees," Journal of Public Economics, 116: 73-88.

Goda, Gopi, Shanthi Ramnath, John Shoven, and Sita Slavov. 2015. "The Financial Feasibility of Delaying Social Security: Evidence from Administrative Tax Data," NBER Working Paper \#21544, September 2015.

Local Government Employees’ Retirement System. "Your Retirement Benefits." https://www.nctreasurer.com/ret/Benefits\%20Handbooks/LGERShandbook.pdf

McGarry, Kathleen. 2014. "Health and retirement: Do changes in health affect retirement expectations?" Journal of Human Resources, 39(3): 624-648.

Novy-Marx, Robert and Joshua Rauh. 2011. "Policy options for state pension systems and their impact on plan liabilities," Journal of Pension Economics and Finance, 10(2): 173-194.

Shoven, John and Sita Slavov. 2014a. "Does It Pay to Delay Social Security?" Journal of Pension Economics and Finance, 13(2): 121-144.

Shoven, John and Sita Slavov. 2014b. "Recent Changes in the Gains from Delaying Social Security," Journal of Financial Planning, 27(3): 32-41.

Teachers' and State Employees' Retirement System. "Your Retirement Benefits" https://www.nctreasurer.com/ret/Benefits\%20Handbooks/TSERShandbook.pdf

Wiatrowski, William. "Supplementing retirement until Social Security begins," Monthly Labor Review, February 1990 pp. 25-28.

Wisconsin Legislative Council. "2012 Comparative Study of Major Public Employee Retirement Systems," December 2013. http://docs.legis.wisconsin.gov/misc/lc/comparative_retirement_study/2012_retirement.p $\underline{\mathrm{df}}$ 
Figure 1. Illustration of Single Life Annuity Options for a Hypothetical Retiree

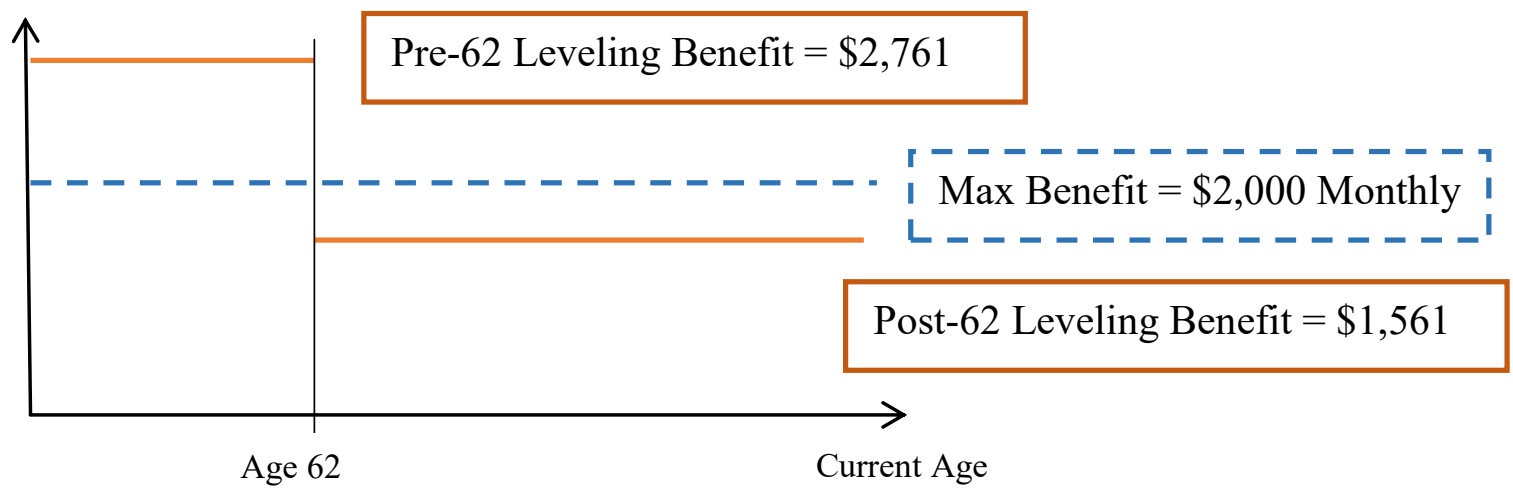

Notes: Calculations are provided in Appendix A. The numbers assume a retiree claims benefits at age 57 and is eligible for a maximum single life benefit of $\$ 2,000$ per month. We assume the retiree is eligible for a reduced Social Security benefit of $\$ 1,200$ at age 62 (this implies a PIA of $\$ 1,600)$. The Social Security Leveling benefit would then be $\$ 2,761$ prior to age 62 and $\$ 1,561$ after age $62(\$ 1,561+\$ 1,200$ yield a level income of $\$ 2,761)$. 
Figure 2. Age and Time Pattern of Social Security Leveling

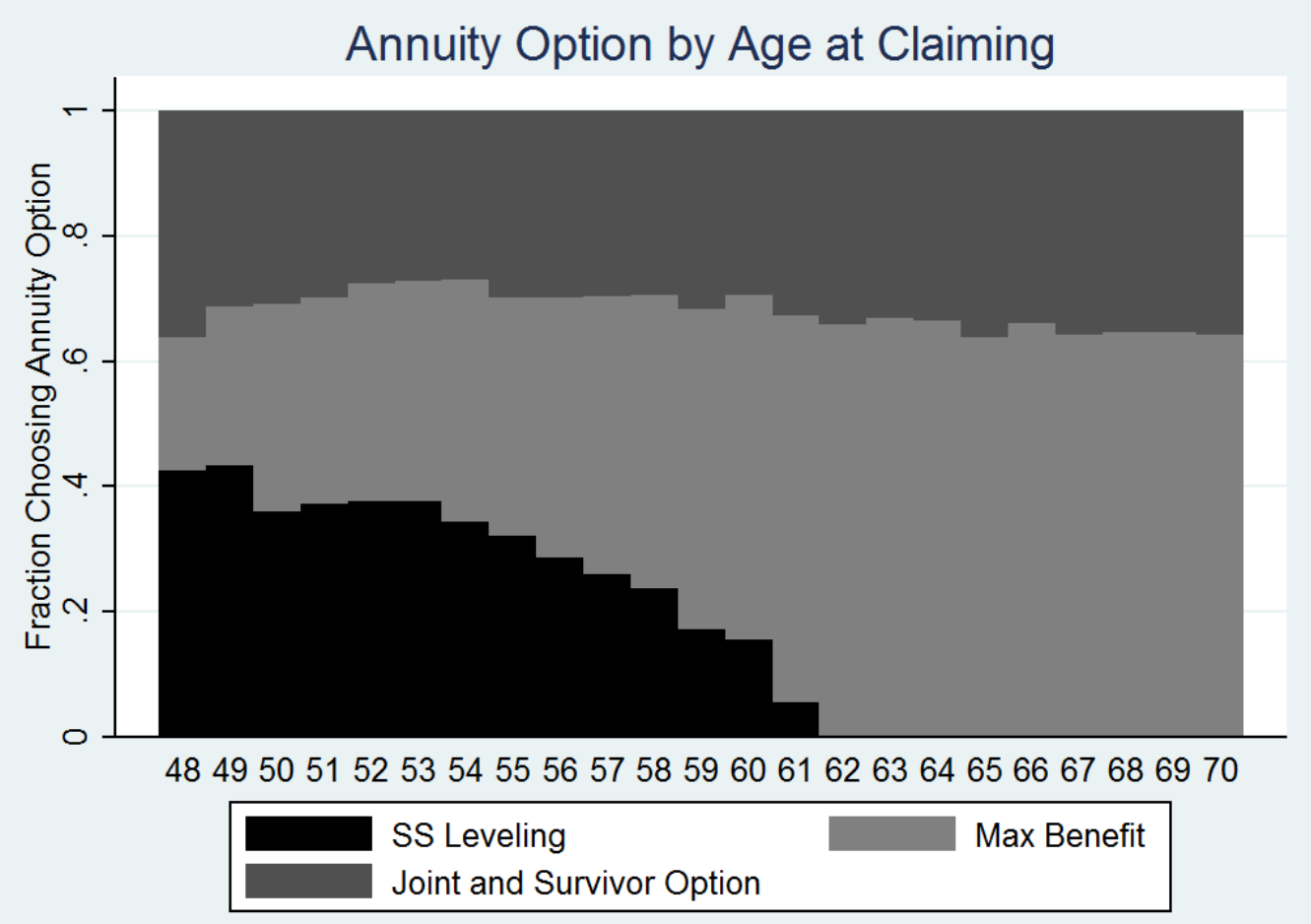

Notes: Sample is all benefit claimants from 2009 to 2014 who were ages 48 to 70 at the time of claiming, $\mathrm{N}=64,784$. 
Table 1. State Annuity Options Social Security Leveling

\begin{tabular}{|c|c|c|c|}
\hline State Plan & $\underline{\text { Age }}$ & Covered Employees & $\underline{\text { Plan Information }}$ \\
\hline Alaska PERS & 65 & $\begin{array}{l}\text { State and local employees, } 11,688 \\
\text { actives }\end{array}$ & $\begin{array}{l}\text { Left SS in 1986, DC in } \\
\text { 2006. Leveling only for DB. }\end{array}$ \\
\hline Idaho PERS & SS FRA & State, local, and teachers, 65,270 actives & \\
\hline Illinois SRS & 66 & State employees, 62,732 actives & \\
\hline Illinois MRF & 62 & Locals, 174,381 actives & \\
\hline Indiana PERF & 62 & $\begin{array}{l}\text { State and local employees, } 145,519 \\
\text { actives }\end{array}$ & $\begin{array}{l}\text { Hybrid plan annuity from } \\
\text { DB component. }\end{array}$ \\
\hline Indiana TRF & 62 & Teachers, 72,872 actives & $\begin{array}{l}\text { Hybrid plan annuity from } \\
\text { DB component. }\end{array}$ \\
\hline Kentucky KERS & 62 & State employees, 46,282 actives & \\
\hline Kentucky CERS & 62 & Local employees, 92,182 actives & \\
\hline Michigan SERS & 65 & State employees & $\begin{array}{l}\text { DB plan frozen } 1997, \text { New } \\
\text { hires in DC plan. }\end{array}$ \\
\hline Michigan PSERS & 62 & Teachers, 236,660 employees & \\
\hline $\begin{array}{l}\text { North Carolina } \\
\text { TSERS }\end{array}$ & 62 & $\begin{array}{l}\text { State employees and teachers, 310,627 } \\
\text { actives }\end{array}$ & \\
\hline $\begin{array}{l}\text { North Carolina } \\
\text { LGERS }\end{array}$ & 62 & Local employees, 121,638 actives & \\
\hline North Dakota TRF & $\begin{array}{l}62 \text { or } \\
\text { SS FRA }\end{array}$ & Teachers, 10,138 actives & \\
\hline Rhode Island ERS & 62 & $\begin{array}{l}\text { State employees and teachers, } 24,378 \\
\text { actives }\end{array}$ & \\
\hline $\begin{array}{l}\text { South Dakota } \\
\text { SDRS }\end{array}$ & 62 & $\begin{array}{l}\text { State and local employees and teachers, } \\
38,207 \text { actives }\end{array}$ & \\
\hline Tennessee CRS & 62 & $\begin{array}{l}\text { State and local employees and teachers, } \\
214,860 \text { actives }\end{array}$ & \\
\hline Vermont SRS & 62 & State employees, 8,158 actives & \\
\hline Vermont TRS & 62 & Teachers, 10,101 actives & \\
\hline Virginia SRS & $\begin{array}{l}62-\mathrm{SS} \\
\text { FRA }\end{array}$ & $\begin{array}{l}\text { State and local employees and teachers, } \\
341,826 \text { actives }\end{array}$ & $\begin{array}{l}\text { Retiree chooses age between } \\
62 \text { and SS FRA }\end{array}$ \\
\hline Wisconsin WRS & 62 & $\begin{array}{l}\text { State and local employees and teachers, } \\
257,254 \text { actives }\end{array}$ & \\
\hline
\end{tabular}

\section{Similar Annuity Option}

Georgia ERS Accelerated Benefit. A monthly benefit equal to 135\% of the Maximum Plan Benefit, payable for the first five continuous years of your retirement. After 5 years, monthly benefit is actuarially reduced.

Notes: This information is based on a review of retirement system websites. The numbers of active employees covered are provided in the 2012 report by the Wisconsin Legislative Council, https://docs.legis.wisconsin.gov/misc/lc/comparative_retirement_study/2012_retirement.pdf. 
Table 2: Hypothetical Relative Value of Benefits by Personal Discount Rates

Present Value of Pension Benefits Claimed at Age 57 Social Security: \$1,200; Maximum Benefit Pension: \$2,000

\begin{tabular}{lcccc} 
& \multicolumn{4}{c}{ Assumed Personal Discount Rate } \\
\cline { 2 - 5 } SS Leveling & $0 \%$ & $2.9 \%$ & $7.25 \%$ & $14.5 \%$ \\
\cline { 2 - 5 } Maximum Benefit & $\$ 569,834$ & $\$ 401,727$ & $\$ 272,972$ & $\$ 179,203$ \\
\multirow{2}{*}{ Percent Difference: (Maximum - Leveling)/Maximum } & & $\$ 273,024$ & $\$ 163,598$ \\
& $11 \%$ & $7 \%$ & $0 \%$ & $-10 \%$ \\
\hline
\end{tabular}

Notes: Details of the calculations are provided in Appendix A. The example is for a retiree claiming benefits at age 57 , with a maximum single life benefit of $\$ 2,000$ per month, and a reduced Social Security benefit of $\$ 1,200$ at age 62. Present values are calculated using the mortality assumptions from the retirement system and the assumed personal discount rate as indicated in column headings. 


\section{Table 3: Theoretical Predictions of Consumption Smoothing}

Category

Description

Those with other sources of income have less need to borrow. Those lower levels of human capital may have more difficulty finding work. Lower levels of wealth result in greater need to borrow.

Predictions for Higher Probability of Choosing Leveling

Time impatient preferences

Lower educated

Poorer health

Less wealth accumulated

Less wealth accumulated

Smaller pension benefit

Low skilled/lower educated

Single individuals

Tenure (ambiguous)

Life Expectancy

Leveling is more appealing to those with shorter life expectancies.

Men

Lower educated

Non-Hispanic black

Self-reported life expectancy

Younger at retirement (ambiguous)

more need to smooth, conditional on not working.

Health

Those in poor health may require additional funds immediately and have lower life expectancy.

Risk Preference

Insure against future risks.

Ambiguous

But less trust in future benefits implies desire for more money now.
Poor health (ambiguous)

$\begin{array}{ll}\text { Financial } & \begin{array}{l}\text { No prediction under consumption } \\ \text { smoothing }\end{array} \\ \text { Knowledge } & \end{array}$


Table 4. Means of Individuals Claiming Retirement Benefits between 2009 and 2014

Variables

$\begin{array}{cc}\text { All } & \text { Claiming } \\ \text { Retirees } & \text { Before 62 }\end{array}$

Number of Benefit Accounts

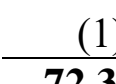

$36.1 \%$

Primary Government (and

Proprietary Unit)

Public Schools

University

Receiving Health Insurance $100 \%$

Receiving Health Insurance 50\%

Male

Years of Service

Years of Service 5-19

Years of Service 20-24

Years of Service 25-29

Years of Service 30+

Final Average Salary

Maximum Initial Benefit Amount
$46.9 \%$

$8.1 \%$

$78.3 \%$

$0.02 \%$

$34.2 \%$

22.9

$35.1 \%$

$15.6 \%$

$19.2 \%$

$30.1 \%$

$\$ 51,447$

$\$ 1,876$ $\mathbf{7 2 , 3 5 0}$

60.7

60.7

$79.1 \%$

$4.3 \%$

$21.0 \%$

$19.7 \%$

(2)

36,883

56.9

56.8

$37.3 \%$

$80.9 \%$

$3.3 \%$

$19.1 \%$

$19.4 \%$

$51.3 \%$

$6.8 \%$

$81.1 \%$

$0.01 \%$

$31.1 \%$

26.9

$14.6 \%$

$13.5 \%$

$24.9 \%$

$47.0 \%$

$\$ 55,208$

$\$ 2,264$

$12.0 \%$

$56.0 \%$

$10.5 \%$

$3.7 \%$

$11.0 \%$

$6.9 \%$

$$
\begin{gathered}
23.4 \% \\
46.7 \% \\
8.2 \% \\
3.3 \% \\
11.1 \% \\
7.4 \%
\end{gathered}
$$

Claiming Survey

Before 62 Respondents and Selecting (Response a Single Life Rate 23\%)

Annuity

(3)

25,839

56.9

56.8

$39.8 \%$

$83.0 \%$

$3.2 \%$

$17.0 \%$

$18.3 \%$

(4)

2,256

56.6

56.6

$34.9 \%$

$83.2 \%$

$4.1 \%$

$16.8 \%$

$15.7 \%$

$55.6 \%$

$7.7 \%$

$83.5 \%$

$0.04 \%$

$19.1 \%$

27.45

$13.2 \%$

$11.6 \%$

$22.5 \%$

$52.7 \%$

$\$ 61,116$

$\$ 53,199$

$\$ 2,534$

$\$ 2,142$

$33.4 \%$

$66.6 \%$

$31.8 \%$

$68.2 \%$

OPT2

OPT3

OPT62

OPT63

Has any other account

$7.5 \%$

$5.5 \%$

$4.3 \%$

$0.12 \%$

$0.09 \%$

$1.7 \%$

$0.13 \%$

Notes: Only primary TSERS and LGERS accounts are included in the sample, as described in Appendix A1. The bottom row indicates the percent of the sample that has both a TSERS and LGERS account in the data. Column (4) excludes survey respondents meeting all other criteria but who have both a TSERS and LGERS account. 
Table 5. Choice of Social Security Leveling Among Single Life Annuitants

\begin{tabular}{|c|c|c|c|c|}
\hline & Mean/Pct & $\begin{array}{c}\text { Baseline } \\
\text { (1) }\end{array}$ & $\begin{array}{l}\text { Health/ } \\
\text { Mortality } \\
\text { (2) }\end{array}$ & $\begin{array}{l}\text { Risk/Time } \\
\text { Preferences } \\
\text { (3) }\end{array}$ \\
\hline \multirow[t]{2}{*}{ Male } & $19.1 \%$ & 0.048 & 0.046 & 0.055 \\
\hline & & $(0.024)^{*}$ & $(0.024)^{*}$ & $(0.025)^{* *}$ \\
\hline \multirow[t]{2}{*}{ Married } & $61.0 \%$ & -0.009 & -0.009 & -0.008 \\
\hline & & $(0.019)$ & $(0.019)$ & $(0.019)$ \\
\hline \multirow[t]{2}{*}{ Non-Hispanic Black } & $16.0 \%$ & 0.166 & 0.175 & 0.158 \\
\hline & & $(0.026)^{* * *}$ & $(0.026)^{* * *}$ & $(0.026)^{* * *}$ \\
\hline \multirow[t]{2}{*}{ Other Race/Ethnicity } & $3.0 \%$ & 0.084 & 0.100 & 0.089 \\
\hline & & $(0.054)$ & $(0.059)^{*}$ & $(0.057)$ \\
\hline \multirow[t]{2}{*}{ BA Degree or more } & $72.3 \%$ & -0.068 & -0.070 & -0.056 \\
\hline & & $(0.024)^{* * *}$ & $(0.024)^{* * *}$ & $(0.024)^{* *}$ \\
\hline \multirow{2}{*}{ Age at Claiming } & 56.6 & -0.036 & -0.036 & -0.036 \\
\hline & & $(0.003)^{* * *}$ & $(0.003)^{* * *}$ & $(0.003)^{* * *}$ \\
\hline \multirow[t]{2}{*}{ Years of Service 5-19 } & $13.2 \%$ & -0.047 & -0.045 & -0.041 \\
\hline & & $(0.044)$ & $(0.044)$ & $(0.044)$ \\
\hline \multirow[t]{2}{*}{ Years of Service $20-24$} & $11.6 \%$ & 0.013 & 0.016 & 0.008 \\
\hline & & $(0.037)$ & $(0.037)$ & $(0.037)$ \\
\hline \multirow[t]{2}{*}{ Years of Service 25-29 } & $22.5 \%$ & 0.035 & 0.036 & 0.037 \\
\hline & & $(0.026)$ & $(0.026)$ & $(0.026)$ \\
\hline \multirow[t]{2}{*}{ Maximum Initial Benefit Amount (1K) } & 2.53 & -0.041 & -0.041 & -0.039 \\
\hline & & $(0.011)^{* * *}$ & $(0.011)^{* * *}$ & $(0.011)^{* * *}$ \\
\hline \multirow[t]{2}{*}{ Self-Reported Health Fair or Poor } & $6.3 \%$ & & -0.090 & \\
\hline & & & $(0.040)^{* *}$ & \\
\hline \multirow[t]{2}{*}{ Missing Response on Self-Reported Health } & $1.2 \%$ & & -0.212 & \\
\hline & & & $(0.106)^{* *}$ & \\
\hline \multirow[t]{2}{*}{ Self-Reported Life Expectancy 80+ } & $65.3 \%$ & & -0.045 & \\
\hline & & & $(0.030)$ & \\
\hline \multirow[t]{2}{*}{ Impatient: Benefit Frame Only } & $18.4 \%$ & & & 0.055 \\
\hline & & & & $(0.029)^{*}$ \\
\hline \multirow[t]{2}{*}{ Impatient: Lottery Frame Only } & $25.8 \%$ & & & 0.066 \\
\hline & & & & $(0.027)^{* *}$ \\
\hline \multirow[t]{2}{*}{ Impatient Both Frames } & $25.1 \%$ & & & 0.092 \\
\hline & & & & $(0.028)^{* * *}$ \\
\hline \multirow[t]{2}{*}{ Risk Averse: Pension Frame Only } & $3.9 \%$ & & & 0.104 \\
\hline & & & & $(0.064)$ \\
\hline \multirow[t]{2}{*}{ Risk Averse: Prize Frame Only } & $17.1 \%$ & & & 0.038 \\
\hline & & & & $(0.056)$ \\
\hline \multirow[t]{2}{*}{ Risk Averse Both Frames } & $70.1 \%$ & & & 0.068 \\
\hline & & & & $(0.055)$ \\
\hline $\mathrm{R}^{2}$ & & 0.13 & 0.14 & 0.14 \\
\hline Number of Obs. & & 2,256 & 2,256 & 2,256 \\
\hline
\end{tabular}

Notes: The dependent variable is having chosen Social Security Leveling, mean 0.317. Data are from administrative records on pension benefit claimants merged with survey responses and include those that chose a single life annuity at retirement. Coefficients are estimates from a LPM with standard errors in parentheses. All specifications include agency type and year of claiming fixed effects, a dummy variable for Hispanic ethnicity (mean 0.05) along with dummy variables for item non-response and for answering "don't know". * $p<0.1 ; * * p<0.05 ; * * * p<0.01$ 
Table 6. The Role of Wealth in the Choice of Social Security Leveling

Male

\begin{tabular}{|c|c|c|}
\hline Mean/Pct & $\begin{array}{l}\text { Baseline } \\
\text { (1) }\end{array}$ & $\begin{array}{l}\text { Wealth } \\
\text { (2) }\end{array}$ \\
\hline \multirow[t]{2}{*}{$19.1 \%$} & 0.048 & 0.044 \\
\hline & $(0.024)^{*}$ & $(0.024)^{*}$ \\
\hline \multirow[t]{2}{*}{$61.0 \%$} & -0.009 & 0.016 \\
\hline & $(0.019)$ & $(0.020)$ \\
\hline \multirow[t]{2}{*}{$16.0 \%$} & 0.166 & 0.138 \\
\hline & $(0.026)^{* * *}$ & $(0.026)^{* * *}$ \\
\hline \multirow[t]{2}{*}{$0.5 \%$} & -0.032 & -0.023 \\
\hline & $(0.127)$ & $(0.126)$ \\
\hline \multirow{2}{*}{$3.0 \%$} & 0.084 & 0.082 \\
\hline & $(0.054)$ & $(0.055)$ \\
\hline \multirow[t]{2}{*}{$72.2 \%$} & -0.068 & -0.048 \\
\hline & $(0.024)^{* * *}$ & $(0.024) * *$ \\
\hline \multirow[t]{2}{*}{56.6} & -0.036 & -0.035 \\
\hline & $(0.003)^{* * *}$ & $(0.003)^{* * *}$ \\
\hline \multirow[t]{2}{*}{$13.4 \%$} & -0.047 & -0.021 \\
\hline & $(0.044)$ & $(0.044)$ \\
\hline \multirow[t]{2}{*}{$11.6 \%$} & 0.013 & 0.031 \\
\hline & $(0.037)$ & $(0.037)$ \\
\hline \multirow[t]{2}{*}{$24.4 \%$} & 0.035 & 0.042 \\
\hline & $(0.026)$ & $(0.026)$ \\
\hline \multirow[t]{2}{*}{2.53} & -0.041 & -0.031 \\
\hline & $(0.011)^{* * *}$ & $(0.011)^{* * *}$ \\
\hline \multirow[t]{2}{*}{$21.2 \%$} & & 0.099 \\
\hline & & $(0.029)^{* * *}$ \\
\hline \multirow[t]{2}{*}{$25.0 \%$} & & 0.063 \\
\hline & & $(0.026) * *$ \\
\hline \multirow[t]{2}{*}{$19.3 \%$} & & 0.109 \\
\hline & & $(0.031)^{* * *}$ \\
\hline \multirow[t]{2}{*}{$43.0 \%$} & & 0.062 \\
\hline & & $(0.026) * *$ \\
\hline \multirow[t]{2}{*}{$21.2 \%$} & & 0.065 \\
\hline & & $(0.028) * *$ \\
\hline \multirow[t]{4}{*}{$10.2 \%$} & & -0.023 \\
\hline & & $(0.040)$ \\
\hline & 0.13 & 0.15 \\
\hline & 2,256 & 2,256 \\
\hline
\end{tabular}

Number of Obs.

Notes: See Table 5. ${ }^{* * *} \mathrm{p}<0.01,{ }^{* *} \mathrm{p}<0.05,{ }^{*} \mathrm{p}<0.1$ 
Table 7: The Role of Financial Literacy in the Choice of Social Security Leveling

\begin{tabular}{|c|c|c|c|c|c|}
\hline & $\begin{array}{l}\text { Mean/ } \\
\text { Pct }\end{array}$ & Baseline & $\begin{array}{c}\text { Objective } \\
\text { Financial } \\
\text { Literacy } \\
(2)\end{array}$ & $\begin{array}{c}\text { Subjective } \\
\text { Financial } \\
\text { Literacy } \\
(3)\end{array}$ & $\begin{array}{l}\begin{array}{c}\text { Over- } \\
\text { confidence }\end{array} \\
\text { (4) }\end{array}$ \\
\hline Male & $19.1 \%$ & $\begin{array}{c}0.048 \\
(0.024)^{*}\end{array}$ & $\begin{array}{c}0.050 \\
(0.025)^{* *}\end{array}$ & $\begin{array}{c}0.052 \\
(0.025)^{* *}\end{array}$ & $\begin{array}{c}0.050 \\
(0.025)^{* *}\end{array}$ \\
\hline Married & $61.0 \%$ & $\begin{array}{l}-0.009 \\
(0.019)\end{array}$ & $\begin{array}{l}-0.009 \\
(0.019)\end{array}$ & $\begin{array}{l}-0.008 \\
(0.019)\end{array}$ & $\begin{array}{l}-0.009 \\
(0.019)\end{array}$ \\
\hline Non-Hispanic Black & $16.0 \%$ & $\begin{array}{c}0.166 \\
(0.026)^{* * *}\end{array}$ & $\begin{array}{c}0.161 \\
(0.027)^{* * *}\end{array}$ & $\begin{array}{c}0.162 \\
(0.027)^{* * *}\end{array}$ & $\begin{array}{c}0.161 \\
(0.027)^{* * *}\end{array}$ \\
\hline Hispanic/Latino & $0.5 \%$ & $\begin{array}{l}-0.032 \\
(0.127)\end{array}$ & $\begin{array}{l}-0.030 \\
(0.127)\end{array}$ & $\begin{array}{l}-0.031 \\
(0.127)\end{array}$ & $\begin{array}{l}-0.031 \\
(0.127)\end{array}$ \\
\hline Other Race/Ethnicity & $3.0 \%$ & $\begin{array}{c}0.084 \\
(0.054)\end{array}$ & $\begin{array}{c}0.086 \\
(0.056)\end{array}$ & $\begin{array}{c}0.087 \\
(0.057)\end{array}$ & $\begin{array}{c}0.087 \\
(0.057)\end{array}$ \\
\hline BA Degree or more & $72.2 \%$ & $\begin{array}{c}-0.068 \\
(0.024)^{* * *}\end{array}$ & $\begin{array}{c}-0.067 \\
(0.024)^{* * *}\end{array}$ & $\begin{array}{c}-0.066 \\
(0.024)^{* * *}\end{array}$ & $\begin{array}{c}-0.067 \\
(0.024)^{* * *}\end{array}$ \\
\hline Age at Claiming & 56.6 & $\begin{array}{c}-0.036 \\
(0.003)^{* * *}\end{array}$ & $\begin{array}{c}-0.036 \\
(0.003)^{* * *}\end{array}$ & $\begin{array}{c}-0.036 \\
(0.003)^{* * *}\end{array}$ & $\begin{array}{c}-0.036 \\
(0.003)^{* * *}\end{array}$ \\
\hline Years of Service 5-19 & $13.4 \%$ & $\begin{array}{l}-0.047 \\
(0.044)\end{array}$ & $\begin{array}{l}-0.045 \\
(0.044)\end{array}$ & $\begin{array}{l}-0.043 \\
(0.044)\end{array}$ & $\begin{array}{l}-0.045 \\
(0.044)\end{array}$ \\
\hline Years of Service $20-24$ & $11.6 \%$ & $\begin{array}{c}0.013 \\
(0.037)\end{array}$ & $\begin{array}{c}0.015 \\
(0.037)\end{array}$ & $\begin{array}{c}0.016 \\
(0.037)\end{array}$ & $\begin{array}{c}0.015 \\
(0.037)\end{array}$ \\
\hline Years of Service 25-29 & $24.4 \%$ & $\begin{array}{c}0.035 \\
(0.026)\end{array}$ & $\begin{array}{c}0.037 \\
(0.026)\end{array}$ & $\begin{array}{c}0.037 \\
(0.026)\end{array}$ & $\begin{array}{c}0.037 \\
(0.026)\end{array}$ \\
\hline $\begin{array}{l}\text { Maximum Initial Benefit } \\
\text { Amount }(1 \mathrm{~K})\end{array}$ & 2.53 & $\begin{array}{c}-0.041 \\
(0.011)^{* * *}\end{array}$ & $\begin{array}{c}-0.040 \\
(0.011)^{* * *}\end{array}$ & $\begin{array}{c}-0.039 \\
(0.011)^{* * *}\end{array}$ & $\begin{array}{c}-0.040 \\
(0.011)^{* * *}\end{array}$ \\
\hline $\begin{array}{l}\text { Financial Knowledge: } \\
\text { Compounding Only }\end{array}$ & $8.3 \%$ & & $\begin{array}{c}0.027 \\
(0.055)\end{array}$ & $\begin{array}{c}0.027 \\
(0.055)\end{array}$ & $\begin{array}{c}0.027 \\
(0.055)\end{array}$ \\
\hline $\begin{array}{l}\text { Financial Knowledge: } \\
\text { Inflation Only }\end{array}$ & $11.6 \%$ & & $\begin{array}{l}-0.002 \\
(0.062)\end{array}$ & $\begin{array}{l}-0.003 \\
(0.062)\end{array}$ & $\begin{array}{l}-0.002 \\
(0.062)\end{array}$ \\
\hline $\begin{array}{l}\text { Financial Knowledge: } \\
\text { Both }\end{array}$ & $66.2 \%$ & & $\begin{array}{l}-0.036 \\
(0.061)\end{array}$ & $\begin{array}{l}-0.036 \\
(0.061)\end{array}$ & $\begin{array}{l}-0.038 \\
(0.063)\end{array}$ \\
\hline $\begin{array}{l}\text { Self-Reported Financial } \\
\text { Knowledge Score }\end{array}$ & 4.27 & & & $\begin{array}{l}-0.006 \\
(0.008)\end{array}$ & \\
\hline $\begin{array}{l}\text { Self-Reported Financial } \\
\text { Knowledge Blank }\end{array}$ & $2.6 \%$ & & & $\begin{array}{l}-0.030 \\
(0.085)\end{array}$ & $\begin{array}{l}-0.003 \\
(0.078)\end{array}$ \\
\hline $\begin{array}{l}\text { Overconfident Financial } \\
\text { Knowledge }\end{array}$ & $12.6 \%$ & & & & $\begin{array}{l}-0.002 \\
(0.034)\end{array}$ \\
\hline $\begin{array}{l}\mathrm{R}^{2} \\
\text { Number of Obs. }\end{array}$ & & $\begin{array}{c}0.13 \\
2,256\end{array}$ & $\begin{array}{c}0.13 \\
2,256\end{array}$ & $\begin{array}{c}0.13 \\
2,256\end{array}$ & $\begin{array}{c}0.13 \\
2,256\end{array}$ \\
\hline
\end{tabular}

Notes: See Table 5. Dummy variables for objective financial knowledge item non-response and responses of "don't know" are included but not reported. *** $\mathrm{p}<0.01, * * \mathrm{p}<0.05, * \mathrm{p}<0.1$ 
Table 8. Ex-Post Regret in Retirement

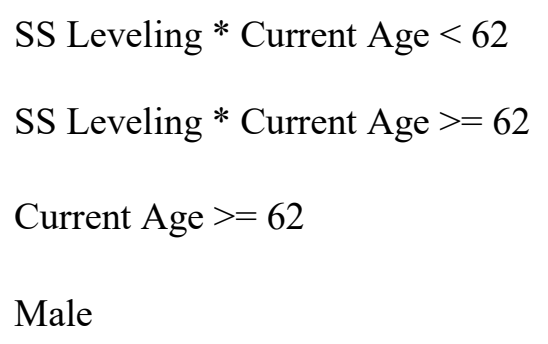

Married

Non-Hispanic Black

Hispanic/Latino

Other Race/Ethnicity

BA Degree or more

Age at Claiming

Years of Service 5-19

Years of Service 20-24

Years of Service 25-29

Maximum Initial Benefit Amount (1K)

Agency Controls

Year of Claiming

\begin{tabular}{|c|c|c|}
\hline $\begin{array}{c}\text { Saved } \\
\text { Enough } \\
(1) \\
\end{array}$ & $\begin{array}{l}\text { Maintain } \\
\text { Standard of } \\
\text { Living } \\
(2)\end{array}$ & $\begin{array}{c}\text { Had Enough } \\
\text { Info } \\
\text { (3) }\end{array}$ \\
\hline-0.054 & 0.076 & -0.002 \\
\hline$(0.028) *$ & $(0.031)^{* *}$ & $(0.022)$ \\
\hline-0.090 & -0.015 & -0.060 \\
\hline$(0.036)^{* *}$ & $(0.039)$ & $(0.029) * *$ \\
\hline 0.061 & 0.069 & 0.030 \\
\hline$(0.037)^{*}$ & $(0.040)^{*}$ & $(0.029)$ \\
\hline 0.081 & 0.062 & -0.047 \\
\hline$(0.026) * * *$ & $(0.028)^{* *}$ & $(0.021)^{* *}$ \\
\hline 0.088 & 0.092 & -0.028 \\
\hline$(0.021)^{* * *}$ & $(0.022)^{* * *}$ & $(0.016)^{*}$ \\
\hline-0.139 & -0.066 & -0.092 \\
\hline$(0.028) * * *$ & $(0.031)^{* *}$ & $(0.022)^{* * *}$ \\
\hline-0.098 & -0.198 & 0.128 \\
\hline$(0.132)$ & $(0.143)$ & $(0.105)$ \\
\hline-0.020 & -0.147 & -0.048 \\
\hline$(0.067)$ & $(0.073)^{* *}$ & $(0.053)$ \\
\hline 0.055 & -0.021 & -0.007 \\
\hline$(0.026)^{* *}$ & $(0.028)$ & $(0.021)$ \\
\hline $\begin{array}{c}0.008 \\
(0.005)^{*}\end{array}$ & $\begin{array}{c}0.008 \\
(0.005)\end{array}$ & $\begin{array}{c}0.002 \\
(0.004)\end{array}$ \\
\hline 0.161 & 0.025 & -0.038 \\
\hline$(0.047)^{* * *}$ & $(0.051)$ & $(0.037)$ \\
\hline 0.050 & -0.046 & -0.022 \\
\hline$(0.040)$ & $(0.043)$ & $(0.032)$ \\
\hline 0.064 & -0.009 & -0.015 \\
\hline$(0.028)^{* *}$ & $(0.030)$ & $(0.022)$ \\
\hline 0.053 & 0.048 & 0.017 \\
\hline$(0.012) * * *$ & $(0.013)^{* * *}$ & $(0.010)^{*}$ \\
\hline $\mathrm{X}$ & $\mathrm{X}$ & $X$ \\
\hline $\mathrm{X}$ & $\mathrm{X}$ & $\mathrm{X}$ \\
\hline 0.09 & 0.04 & 0.03 \\
\hline 2,146 & 2,138 & 2,151 \\
\hline 0.335 & 0.530 & 0.841 \\
\hline
\end{tabular}

Mean Dependent Variable

Notes: Data are from a survey of individuals who initiated retirement benefits from 2009-2014, chose a single life annuity option (max benefit or SS leveling), and were younger than age 62 at the time of claiming. Administrative records and survey responses are as of spring 2015. Dependent variables are indicated in the column headings. Details are provided in the appendix. $* * * p<0.01, * * p<0.05, * p<0.1$ 


\section{Appendix A: Social Security Leveling Calculations}

In this appendix, we present detailed calculations on how the North Carolina retirement systems derive the initial benefit at retirement for the two single life annuity options offered to retirees: the maximum benefit and the Social Security Leveling annuity. The initial monthly benefit amount at retirement for individuals selecting the Social Security Leveling benefit is calculated relative to the initial maximum benefit available to the retiree, as described in the manuscript text. Throughout this exercise, we assume no cost of living increases (COLAs) in future benefits to be consistent with the way that the retirement system performs their valuations for all annuity options. ${ }^{23}$ The administrative records combined with plan documents include information on all inputs to this benefit formula, as well as the value for $B_{M A X}$.

The leveling factor, $F$, is derived from taking a present value calculation of the maximum benefit option taken at different ages. We define $\boldsymbol{A n n}(\boldsymbol{A}, \boldsymbol{C})$ as the present value at retirement age $\boldsymbol{A}$ of the maximum benefit annuity claimed at the age of starting Social Security, $\boldsymbol{C}$. This value is then compared to the present value of an immediate maximum benefit annuity at age $\boldsymbol{A}$, referred to as $\operatorname{Ann}(\boldsymbol{A}, \boldsymbol{A})$. In the current policy, the age of assumed Social Security claiming, $C$, is age 62. To calculate the present values, the retirement system uses an assumed maximum lifespan of 120 years with survival probabilities taken from the retirement system's experience study reports and the mortality tables reference therein. Prior to 2012, the retirement system used the 1984 experience study estimates, ("Early and Optional Retirement Factor Tables", October 1, 1984). Beginning in 2012, the retirement system now uses the 2012 experience study report estimates. ${ }^{24}$ The discount rate, $r_{N}$, was $7.5 \%$ prior to 2012 and was modified to $7.25 \%$ in 2012 .

The present value of an annuity deferred to age $C$ calculated at age $A$ is:

$$
\text { (A.1) } \quad \operatorname{Ann}(A, C)=\boldsymbol{B}_{M A X} *\left[\left(\sum_{S=C+1}^{120} \frac{\text { Survival }_{C}^{S}}{\left(1+r_{N}\right)^{s-C}}\right)+\text { CtsAdj }\right] * 12 * \frac{\text { Survival }_{A}^{C}}{\left(1+r_{N}\right)^{C-A}}
$$

\footnotetext{
${ }^{23}$ An assumption of no COLAs is also appropriate given the recent historical rates at which COLA's have been given; specifically, COLAs of $1 \%$ were given in both 2012, and 2014, while inflation averaged $1.6 \%$ since July 2007.

${ }^{24}$ In 2017 , the retirement system is adopting new estimates, but this is outside the timeframe studied in this paper.
} 
The value of $\boldsymbol{A n n}(\boldsymbol{A}, \boldsymbol{C})$ is calculated separately for men and women and then the rates are "blended" by multiplying male by 0.4 and female by 0.6 and summing together. ${ }^{25}$ The annuity values are also adjusted by the industry-standard 11/24ths adjustment for monthly payment, denoted CtsAdj in equation (A.1). Thus, theoretically the Social Security Leveling option is cost-neutral to the retirement system relative to the maximum benefit option, using the assumptions established by the Board of Trustees of the two retirement plans. However, the discount rates used in the calculation, $\mathrm{r}_{\mathrm{N}}$, are $7.25 \%$ from $2012-2014$ or $7.5 \%$ from $2009-2011$. These are quite high relative to market rates, so the two options are not necessarily identical in present value terms for the retiree unless she also has a high personal discount rate. See Figure 2 for an illustration of this.

To construct the factor that is applied to the maximum benefit, the retirement system takes the ratio of the present value of the annuity benefit deferred to age $\boldsymbol{C}$ relative to the present value of the annuity benefit claimed at the current age, $A$.

(A.2) $\quad F(A, C)=(\operatorname{Ann}(A, C) / \operatorname{Ann}(A, A))$

Thus, the Social Security Leveling factor is only a function of age at initial claiming and age at deferral, since the benefit level $B_{M A X}$ will cancel out.

\section{Present Value:}

For present value calculations, we retain the pension system experience study survival rates and use alternative personal discount rates $r_{i}$. In calculating the present value of the benefit streams, we vary the personal discount rate used. Note that the discount rate employed by the retirement system to calculate the leveling benefit, 7.25 percent, should yield an identical present value of the leveling and maximum benefit options holding constant the other system assumptions. We calculate present values using lower rates, including the rate of 2.9 percent adopted by Shoven and Slavov (2014a) in their analysis of the present value of Social Security benefits.

The calculations are presented below. Here $A$ denotes the age at claiming the retirement pension and $C$ denotes the age at claiming Social Security. The notation uses $r_{i}$ for the discount

\footnotetext{
${ }^{25}$ The convention of using a fixed proportion of males and females could lead to an underestimate of the true cost-neutral discounting since we find about three-quarters of those selecting a single-life annuity are women.
} 
rate used in the present value calculation and $r_{N}$ for the discount rate used by the retirement system for calculating the leveling factors. We adopt the retirement system's approach of using mortality tables to derive a probability of survival and sum the present value until age 120 .

Because the maximum benefit is simply the same dollar value monthly until death, the present value can be written as:

$$
\text { (A. 3) } P V_{M A X}[A]=B_{M A X} *\left[\left(\sum_{\boldsymbol{a}=\boldsymbol{A}+\mathbf{1}}^{\mathbf{1 2 0}} \frac{\text { Survival a }_{A}^{a}}{\left(\mathbf{1}+\boldsymbol{r}_{\boldsymbol{i}}\right)^{-\boldsymbol{a}}}\right)+C t s A d j\right] * 12
$$

The present value of the leveling option must consider separately the two time periods:

$$
\begin{aligned}
& \text { (A. 4) } P V_{L E V}[A]= \\
& B_{M A X}\left[\sum_{a=A+1}^{120} \frac{\text { Survival }_{A}^{a}}{\left(1+r_{i}\right)^{a-A}}+C t s A d j\right] * 12+\boldsymbol{S S} * \boldsymbol{F} *\left[\sum_{\boldsymbol{a}=\boldsymbol{A}+\mathbf{1}}^{\mathbf{1 2 0}} \frac{\text { Survival }_{A}^{a}}{\left(\mathbf{1}+\boldsymbol{r}_{\boldsymbol{i}}\right)^{a-A}}+C t s A d j\right] * 12- \\
& S S *\left[\sum_{a=C+1}^{120} \frac{\text { Survival }_{C}^{a}}{\left(1+r_{i}\right)^{a-C}}+\text { CtsAdj }\right] * 12 * \frac{\text { Survival }}{\left(1+r_{i}\right)^{C-A}}
\end{aligned}
$$

Here, $\mathrm{F}$ is the ratio of the present value of benefits at age $\mathrm{A}$ of an annuity claimed at age $\mathrm{C}$ to the present value of benefits at age A claimed immediately. Thus, if the personal discount rate and subjective survival probabilities are identical to the assumptions used in calculating $\mathrm{F}$, then the second two terms basically cancel out and the present value of the Maximum Benefit and Social Security Leveling options are nearly identical.

\section{Simulation Exercise:}

For this exercise, we create a hypothetical retiree that is eligible for an immediate TSERS Maximum Benefit of $\$ 2,000$ and an early retirement estimate of $\$ 1,200$. Using the notation from the equations above, Appendix Table A1 presents the comparison between the Maximum Benefit option and the Social Security Leveling option. The present values are calculated as above and include both the pension and Social Security benefit. We calculate this separately for an individual claiming at age 52 and an individual claiming at age 57. 


\section{Definitions:}

$\mathrm{r}_{\mathrm{N}}$ : Discount rate used by the retirement system to price the factors.

A: Age at pension benefit claiming.

C: Age at Social Security benefit claiming.

$\mathrm{B}^{1}$ : Pension benefit during time period 1 (before Social Security Claiming)

$\mathrm{B}^{2}$ : Pension benefit during time period 2 (after Social Security Claiming)

SS: Social Security benefit starting at age C.

$r_{i}$ : Discount rate used by the individual to weigh future benefits at time 0 .

Appendix Table A1: Comparison of Max and Social Security Leveling Age 57

Age at Claiming: 57

Annuity

$\begin{array}{llllllll}\text { Type } & \mathrm{r}_{\mathrm{N}} & \mathrm{A} & \mathrm{C} & \mathrm{F} & \mathrm{B}^{1} & \mathrm{~B}^{2} & \text { SS }\end{array}$

Chosen

\begin{tabular}{llllllll}
\hline Max & N/A & 57 & 62 & N/A & $\$ 2,000$ & $\$ 2,000$ & $\$ 1,200$ \\
Level 62 & $7.25 \%$ & 57 & 62 & 0.6344 & $\$ 2,761$ & $\$ 1,561$ & $\$ 1,200$
\end{tabular}

Appendix Table A2: Comparison of Max and Social Security Leveling Age 52

Age at Claiming: 52

Annuity

$\begin{array}{lllllllll}\text { Type } & \mathrm{r}_{\mathrm{N}} & \mathrm{A} & \mathrm{C} & \mathrm{F} & \mathrm{B}^{1} & \mathrm{~B}^{2} & \text { SS }\end{array}$

Chosen

\begin{tabular}{llllllll}
\hline Max & N/A & 52 & 62 & N/A & $\$ 2,000$ & $\$ 2,000$ & $\$ 1,200$ \\
Level 62 & $7.25 \%$ & 52 & 62 & 0.4147 & $\$ 2,498$ & $\$ 1,298$ & $\$ 1,200$
\end{tabular}




\section{Appendix Table A.3: Present Value Calculations Age 57 Claiming}

Age at Claiming: 57

\section{Social Security: \$1,200; Maximum Benefit Pension: \$2,000}

Assumed Personal Discount Rate

\begin{tabular}{lcccc} 
& $0 \%$ & $2.9 \%$ & $7.25 \%$ & $14.5 \%$ \\
\cline { 2 - 5 } SS Leveling & $\$ 569,834$ & $\$ 401,727$ & $\$ 272,972$ & $\$ 179,203$ \\
Maximum Benefit & $\$ 639,017$ & $\$ 429,908$ & $\$ 273,024$ & $\$ 163,598$ \\
Percent Difference: & (Maximum - Leveling)/Maximum & & \\
& $11 \%$ & $7 \%$ & $0 \%$ & $-10 \%$ \\
\hline
\end{tabular}

Appendix Table A.4: Present Value Calculations Age 52 Claiming

Age at Claiming: 52

Social Security: \$1,200; Maximum Benefit Pension: \$2,000

Assumed Personal Discount Rate

SS Leveling

\begin{tabular}{cccc}
$0 \%$ & $2.9 \%$ & $7.25 \%$ & $14.5 \%$ \\
\hline$\$ 626,651$ & $\$ 432,804$ & $\$ 289,575$ & $\$ 186,527$ \\
$\$ 747,751$ & $\$ 477,447$ & $\$ 289,535$ & $\$ 168,008$
\end{tabular}

Maximum Benefit

$\$ 747,751$

$\$ 477,447$

.

Percent Difference: (Maximum - Leveling)/Maximum
$16 \%$
$9 \%$
$0 \%$
$-11 \%$ 


\section{Appendix B: Sample construction and restrictions}

\section{Administrative Records}

The retirement system maintains records for several retirement plans including firefighters, judicial classes, and the legislature. We construct our data using administrative records on active retirement benefit accounts that were initiated between January 1, 2009 and December 31, 2014. We only consider retirement accounts from the TSERS or LGERS retirement systems. We exclude any accounts that are suspended. We do not include ancillary accounts from other systems but do retain an indicator if the individual has other benefit accounts, which might include the transfer benefit option or another retirement system such as the legislature or firefighters. ${ }^{26}$ We also exclude any accounts that were closed for any reason, including disability, withdrawal, or transfer of benefits. We exclude firefighters and law enforcement officers that are within TSERS and LGERS, since the eligibility rules are different for those plans.

We confirm that the remaining 80,241 benefit records are unique accounts - individuals may only receive one benefit from TSERS and one benefit from LGERS. We make further exclusions as listed in Appendix Table B1 below. These include: recorded years of service is less than 5 years, termination of employment before 2008, days between termination and claiming greater than one year, and missing gender code. We end up with 72,350 unique benefit accounts representing 72,254 individuals with one account and 96 individuals with both a TSERS and LGERS account.

To create the sample for Table 4, Column (2), we exclude individuals claiming at age 62 and above. We also exclude individuals whose age at claiming or years of service combination does not match the requirements for either an early or normal benefit account. This yields 36,883 observations. To create the sample for Table 4, Column (3), we only keep those choosing a maximum benefit or Social Security leveling option, $N=25,839$. Finally, we sent a survey to

\footnotetext{
${ }^{26}$ While we focus solely on those accounts in TSERS and LGERS, individuals may also have accounts with these other systems. Where relevant, we include an indicator variable for the individual having an additional membership in another retirement plan. About $1 \%$ of our sample has both an active TSERS and LGERS retirement benefit. For those individuals we keep both records and treat them as separate observations but retain an indicator variable.
} 
9,650 of the eligible benefit claimants. Our final sample for analysis includes 2,256 respondents for a response rate of $23 \%$.

Appendix Table B2 presents a comparison between our sample and data from the American Community Survey (ACS). For the ACS data, we used the 2010-2014 5-year Public Use Microdata Samples (PUMS). We include individuals aged 50 or older. We consider those who report labor market participation last year that were state or local government employees and worked full time (14+ weeks and 30+ hours per week worked). The sample is then restricted to those that did not work last week, that last worked within the past 12 months, and that are currently either unemployed or not in the labor force. This is an approximation to recent retirees. Our ACS data will exclude individuals that claimed benefits from a public sector retirement system but immediately took another job.

\section{Key Policy Details}

Here we outline some key policies that were in place during the 2009-2014 time period.

\section{Return to work:}

Our data will include some individuals that have "retired" but are still working within the system according to the rules below.

○ Pension benefits can be received while working at any other job not covered by that pension. This includes a TSERS employee working under LGERS and vice versa.

○ Pension benefits can be received while working for a job at the prior employer as long as the position is not eligible for pension benefits (typically a part-time position).

○ Pension benefits will be suspended if an individual works in a job that is covered by the same pension. After 3 years of service, the earned benefits can be combined into one account. If 3 years of service are not reached, the new account is not eligible for pension benefits and must be withdrawn as a lump sum. 


\section{Multiple benefit accounts:}

We retain individuals that have multiple benefit accounts and include TSERS and LGERS accounts separately in the data. The rules on maintaining multiple benefit accounts are below.

- Each retirement benefit account can be paid separately and there are no restrictions on coordinating annuity type or timing. Individuals with multiple accounts have the option to consolidate them by transferring service from one account to another. The average final compensation (AFC) used is that from the receiving account, while the years of service is the sum of all accounts. We cannot track in the data whether the benefit account is the sum of multiple benefits earned under different retirement systems.

○ An individual may have multiple membership accounts due to:

- Long break in work

- Return to work

- Work with a different retirement system (first TSERS, then LGERS etc.)

\section{Years of Service:}

In our data, we only observe creditable service, which is a combination of tenure and optional purchased service.

○ Creditable service: service calculation used for determining benefit level

- Membership service

- Purchased service: withdrawn service, military service, out-of-state, temporary, educational leave, workers' compensation, community service, parental leave, extended illness leave, etc. Also: unused sick leave and vacation time.

○ Contributory service: service calculation used for determining eligibility Using date of hire and date of termination, which are measured with some error, we estimate that most individuals have about 6-8 months of purchased service on top of membership service. 
Appendix Table B1: Sample Construction

\section{Restriction}

All eligible benefit accounts

Reported service credit $<5$ years

Terminated prior to 2008

Days between termination and benefit claiming $>=366$

Missing gender code

Full Administrative Records

Table 4, Column (1)

Remove combinations of age and YOS that are not consistent with eligibility

Only those claiming prior to 62

Full Administrative Records for Claimants Age $<62$

Table 4, Column (2)

Single life Annuity Claimants Age $<62$

Table 4, Column (3)

Single life Annuity Claimants, Age $<62$, Validated

Email Address and Sent the Survey

Survey Sample Responses

299

72,051

35,168

36,883

36,883

25,839

9,650

2,256

Completed Survey Response

Table 4, Column (4)

Note: The survey response rate was $23 \%$ for the sample used in this paper. 


\section{Appendix Table B2: Data Representativeness}

Variables

Number of Observations

Age at Survey

Age at Claiming

Age

Male

Married

Non-Hispanic Black

Hispanic/Latino

Other Race/Ethnicity

Education

BA or above
ACS

United States

ACS

Survey

North Carolina

Respondents

(Response Rate $23 \%)$

\begin{tabular}{ccc} 
& & $23 \%)$ \\
\hline$(1)$ & $(2)$ & $(3)$ \\
\hline 9,524 & 363 & 2,256
\end{tabular}

60

(40\% age $62+$ )

56.2

$35.0 \%$

$67.1 \%$

56.5

$26.9 \%$

$71.4 \%$

$19.1 \%$

$61.0 \%$

$13.2 \%$

$16.9 \%$

$16.0 \%$

$8.4 \%$

$0.7 \%$

$0.5 \%$

$4.5 \%$

$2.4 \%$

$3.0 \%$

$47.0 \%$

$52.7 \%$

$72.3 \%$

Notes: ACS data include individuals ages 50 to 62 who were working at a state or local government employer last year but are not currently working. Data from our survey include individuals that claimed retirement benefits in North Carolina and were younger than age 62 . Survey respondents are disproportionally higher educated, less likely to be married, and more likely to be female than the population average. 


\section{Appendix C: Definition of Key Survey Variables}

\section{$\underline{\text { Risk and Time Preferences }}$}

\section{Impatient: Lottery Frame}

Suppose that you won a prize that is worth $\$ 1000$ if you take it today. Alternatively, you could wait one year to claim the prize and be guaranteed to receive $\$ 1200$. Would you claim the $\$ 1000$ dollars today, or would you wait one year for the $\$ 1200$ ?

\section{O Claim \$1000 today}

O Wait one year and claim $\$ 1200$

O Not sure

\section{Impatient: Benefit Frame}

Imagine you are 65 years old, and you (and your spouse/partner) are receiving \$1000 per month in Social Security benefits. Suppose you were given the choice to reduce that benefit by half, to $\$ 500$ per month. This one-half benefit reduction would continue for as long as you (and your spouse/partner) live. In return, you would be given a one-time, lump-sum payment of $\$ 80,500$. Would you take the $\$ 1000$ monthly benefit for life, or the reduced monthly benefit combined with the lump sum payment?

O Take the $\$ 1000$ monthly benefit

Take the reduced benefit and the lump sum

O Not sure

\section{Risk Adverse: Pension Frame}

Suppose that you are about to retire and have two choices for your pension benefit. Pension A gives you an income equal to your pre-retirement income. Pension B has a $50 \%$ chance of providing a benefit worth double your pre-retirement income and a 50\% chance of providing a benefit worth $20 \%$ less than your pre-retirement income. Which pension benefit would you choose?
O Pension A
O Pension B
O Not sure 


\section{Risk Adverse: Prize Frame}

Suppose that you are offered a choice between two prizes. If you choose Prize A, you are guaranteed to receive $\$ 1000$. Alternatively, if you choose prize $\mathrm{B}$, you will have a 50-50 chance of receiving $\$ 2200$ and a 50-50 chance of receiving $\$ 0$. Which prize would you choose -- Prize A or Prize B?
O Prize A
O Prize B
O Not sure

\section{Financial Knowledge}

\section{Financial Knowledge: Compounding}

If you have $\$ 100$ in your savings account, and the annual interest rate is $2 \%$, how much money will you have in your account after five years?
O More than $\$ 102$
$0 \$ 102$
0 Less than $\$ 102$
O Do not Know

\section{Financial Knowledge: Inflation}

If the current interest rate on your savings account is $1 \%$ per year, and the inflation rate is $2 \%$ per year, how much do you think you will be able to buy with your money a year from now?

O A larger amount than you can buy now

O Exactly the same amount as you can buy now

O A smaller amount than you can buy now

O Do not know

\section{Self-Reported Financial Knowledge:}

On a scale from 1 to 7 (where 1 means very low, and 7 means very high), how would you rate your financial knowledge? 


\section{Well-Being Outcomes:}

\section{Financial Fragility}

How confident are you that you could come up with $\$ 2,000$ if an unexpected need arose within the next month?

O I am certain I could come up with the full $\$ 2,000$.

0 I could probably come up with $\$ 2,000$.

0 I probably could not come up with $\$ 2,000$.

0 I am certain I could not come up with $\$ 2,000$.

Dependent variable is a binary indicator of NOT choosing the first option (including skipping the question).

The last three retiree well-being outcomes in Table 6 of the text are derived from the following questions. The outcome is binary with a 1 for "agree" or "strongly agree" and 0 otherwise.

Please indicate whether you agree or disagree with the following statements regarding your choices at retirement [Strong Disagree; Disagree; Somewhat Disagree; Somewhat Agree; Agree; Strongly Agree]:

I believe I had enough information to make good decisions regarding my retirement from North Carolina public employment.

I believe I saved enough for retirement while working.

I believe my standard of living is the same as, or better than, it was before I retired from NC public employment. 